\title{
A JAVULÓ ISKOLÁZOTTSÁG HATÁSA AZ ÉLETTARTAMOKRA MAGYARORSZÁGON
}

\section{Bálint Lajos}

\section{ÖSSZEFOGLALÓ}

A kilencvenes évek elején epidemiológiai fordulatra került sor Magyarországon, a rákövetkező évtizedekben a népesség várható élettartama folyamatosan emelkedett. A legtöbb tanulmány az életkilátások javulását az egészségügyi ellátás színvonalában bekövetkezett változásokkal, korszerübb terápiás eljárásokkal magyarázza. Mások az életszínvonal javulását, az egészségmagatartási szokások és attitűdök módosulásának a fontosságát emelik ki. Az iskolázottság és a halandóság között jól dokumentáltan erős kapcsolat van. Ennek ellenére a változások magyarázatakor kevésbé hangsúlyozott az a tény, hogy az elmúlt évtizedekben jelentősen javult a magyar társadalom iskolázottsága. Nőtt az érettségizettek és a diplomások, míg jelentősen csökkent az alapfokú végzettséggel sem rendelkezők aránya. A demográfiában ismert dekomponálási technikát alkalmazva az élettartamok változását felbontottuk a népesség összetételében (P-hatás) és a csoportok mortalitásában (M-hatás) bekövetkezett változásra. A népesség struktúrájában bekövetkezett kedvező változás a nőknél 1,5, a férfiaknál 1,45 évvel járult hozzá az élettartam 1990 és 2011 között tapasztalt növekedéséhez. Úgy is fogalmazhatunk, hogy a vizsgált időszak alatt bekövetkező élettartam-javulásból a populációs hatás 8,5 naptári év fejlődésével volt egyenértékű a nőknél, és 6,5 évnyi éves átlagos javulást tett ki a férfiaknál. A tanulmány legfontosabb üzenete az, hogy az oktatáspolitika egyben rendkivül hatékony egészségpolitikai eszköz is. Az iskolázottság olyan tudás megszerzését teszi lehetővé, ami segítségünkre van a betegségek megelőzésében és kezelésében. Fontos, hogy a döntéshozók és az egészségügyben dolgozó szakemberek megértsék az ok- 
tatás jelentőségét, amely nem csak az életkilátások tartós javulását eredményezi, de egyúttal képes a társadalmi-gazdasági egyenlőtlenségeket is mérsékelni.

Tárgyszavak: halandóság, felnőtt várható élettartam, társadalmi halandósági egyenlőtlenségek, mortalitási és strukturális hatás szerinti dekomponálás.

Bálint Lajos, KSH Népességtudományi Kutatóintézet

E-mail: balint@demografia.hu

\section{BEVEZETÉS}

Magyarországon 1993-ban epidemiológiai korszakváltásra került sor, jelentős javulás következett be a népesség életkilátásaiban, csökkent a felnőtt népesség halandósága, számottevően javultak az időskorú nők túlélési esélyei, a középkorú férfiak mérséklődő mortalitásának köszönhetően az évtizedeken át tartó mortalitási krízis nyomai is behegedni látszanak. A nőkhöz hasonlóan az időskorú férfiak halandóságának javulása is érdemben hozzájárult a várható élettartam növekedéséhez (Bálint, 2016). A fejlődést a nyugati (Vallin, 2013; Willekens, 2016) és más közép-európai országokhoz hasonlóan (Fihel and Pecholdová, 2017; Rychtařiková, 2004; Gavurova and Vagasova, 2018) Magyarországon is a keringési rendszer (BNO10: 100-199) okozta halandóság kedvező alakulása befolyásolta a leginkább (Bálint, 2016; Józan, 2012).

A legtöbb tanulmány az élettartam-növekedést az egészségügyi ellátás javulásával, az új orvosi fejlesztésekkel, elsősorban a szív- és érrendszeri betegségek szűrésének, megelőzésének és kezelésének növekvő lehetőségeivel (Balogh et al., 2010; Belicza és Jánosi, 2012; Gero et al., 2015; Józan, 2004, 2012), valamint az életszínvonal javulásával, az egészségmagatartási szokások és attitűdök változásával kapcsolják össze (Gero et al., 2015; Józan, 2004; Bálint, 2016). Kisebb figyelmet kapott az a tény, hogy az elmúlt évtizedekben a társadalom jelentősen átalakult, iskolázottsága sokat javult, az új generációk sokkal alaposabb ismeretekkel rendelkeznek az egészségkárositó magatartásformákkal és a betegségek megelőzésével kapcsolatban, mint a szüleik.

Az iskolázottság a felnőttkori halandóság fontos differenciáló tényezője. Magasabb iskolai végzettséghez alacsonyabb halálozási kockázatok kapcsolódnak. Az iskolázottság javulása többek szerint meghatározó szerepet játszott a 
közép-kelet-európai régió országaiban bekövetkezett élettartam-javulásban (Hablicsek, 2007; Fihel and Pecholdová, 2017). A tanulmány a magyar felnőtt népesség várható élettartamának változását vizsgálja az 1990 és 2011 körüli években, arra a kérdésre keresve a választ, hogy a népesség struktúrájában és mortalitásában bekövetkezett változás milyen mértékben járult hozzá a várható élettartam javulásához.

\section{AZ ISKOLÁZOTTSÁG ÉS A HALANDÓSÁG KAPCSOLATA}

Az elmúlt évtizedekben napvilágot látott publikációk szerint a magasabb iskolázottságúak alacsonyabb mortalitási rátákkal (Kalediene and Petrauskiene, 2005), jobb túlélési esélyekkel, kisebb halálozási valószínűségekkel (Winkleby and Cubbin, 2003), magasabb várható élettartammal (Hummer and Hernandez, 2013; Sihvonen et al., 1998) rendelkeznek, mint az alacsonyabb iskolázottságúak. Az iskolázottság és a halandóság közötti inverz kapcsolat a legfontosabb halálokok szinte mindegyikénél megfigyelhető (Steenland et al., 2004; Black et al., 1982; Marmot et al., 1984; Sorlie et al., 1995; Lleras-Muney, 2005; Phelan et al., 2004; Sasson, 2016; Kovács, 2007), mivel a társadalmi státus csaknem mindent érint, ami befolyással van az egészségre (Ross and Mirowsky, 2003).

A társadalmi státus szerinti éles törésvonalak nem csak a mortalitásban, hanem a jobb egészségi állapotban, a fizikai funkciókban is megfigyelhetők (Ross and Wu, 1995; Cutler and Muney, 2006) A mortalitáshoz hasonlóan a megbetegedések is erősen kapcsolódnak a társadalmi struktúrában elfoglalt pozícióhoz (Prescott and Vesbo, 1999; Schultz et al., 2018; Clegg et al., 2009). A magasabb iskolázottságúak nem csupán tovább élnek, de kedvezőbb megbetegedési statisztikáik miatt hosszabb egészségben eltöltött életre is számíthatnak (Crimmins and Saito, 2001; Sihvonen et al., 1998; Unger and Schulze, 2013). Mivel az iskolázottság egészségre gyakorolt hatásai számottevőek, az oktatásba történő beruházás a jobb egészség elérésének költséghatékony eszközének is bizonyulhat (Lleras-Muney, 2005).

A szocioökonómai dimenzióinak mindegyike, így az iskolázottság (Elo and Preston, 1996; Preston and Elo, 1995; Shkolnikov et al., 1998; Kalediene and Petrauskine, 2000), a foglalkozás (Dolbhammer et al., 2005; Banks et al., 2006), a jövedelem (Henriksson et al., 2006; McDonough, 1997) és a vagyoni helyzet (Hummer and Larisci, 2011) is hatással van a felnőttkori túlélési esélyekre. A társadalmi-gazdasági státus különböző indikátorai bonyolult módon kapcsolódnak egymáshoz (Lahelma and Valkonen, 1990), az empirikus tapasztalatok 
szerint ugyanakkor önálló, független hatást gyakorolnak az egészségi állapotra (Geyer et al., 2006; Vandenheede et al., 2014). A demográfiai kutatásokban a státusdimenziók közül az iskolázottság bizonyult a legfontosabb magyarázóváltozónak. A társadalmi rétegződés más komponenseivel szemben az iskolai végzettség több tartalmi és elemzési szempontból előnyös tulajdonsággal rendelkezik.

A szocioökonómiai státus aspektusai közül az iskolai végzettség gyakorolja a legerősebb hatást az egészségi állapotra és a mortalitásra (Miech et al., 2011; James et al., 2017). Az iskolázottság hatása más szocioökonómiai változók (Elo and Preston, 1996; Rogers et al., 2000; Grigoriev et al., 2019) és fontos kockázati tényezők kontrollja mellett is fennáll (Howard et al., 2005). Az iskolázottság egészségre gyakorolt hatását bonyolult ökonometriai elemzések is meggyőzően alátámasztják, és a kapcsolat kauzális jellegét hangsúlyozzák (Hummer and Larisci, 2011; Feinstein et al., 2006).

Az iskolázottságnak kulcsszerepe van a stratifikációs rendszerben megszerezhető pozíciók elnyerésében, befolyásolja a munkanélküliség kockázatát, meghatározza az elnyerhető álláshelyek körét, valamint az általuk megszerezhető jövedelmet. Az egészségi állapot romlása jelentősen befolyásolhatja a foglalkozási és a jövedelmi helyzetet, ezzel szemben a felnőttkori egészségkárosodás az iskolai végzettségre már nem hat vissza. Az egészséggel kapcsolatos szelekciós hatás vagy fordított okság (reverse causality) előfordulása kevésbé valószínű (Elo and Preston, 1996; Preston and Elo, 1995; Sihvonen et al., 1998). Az egészségi állapot és a szocioökonómiai státus közötti pozitív kapcsolat nagyrészt a SES (socioeconomic status) egészségre gyakorolt hatása miatt van és nem fordítva, a rossz egészségi állapotúak lefelé történő mobilitása nem magyarázza az összefüggést (Ross and Wu, 1995). Az iskolai végzettség befolyásolja a foglalkozási pályát és a kereseteket, így az iskolázottság egészségre gyakorolt hatását a foglalkozás és a jövedelem közvetítheti (Elo and Preston, 1996; Ross and Mirowsky, 1999). A jövedelemhez képest az iskolázottság szorosabban kapcsolódik az egészségmagatartás különböző elemeihez (Ross and Mirowsky, 1998).

A szocioökonómiai státus dimenziói közül az iskolázottság mellett technikai természetű előnyök is felsorakoztathatók. Az iskolázottság minden egyén esetében meghatározható, egyaránt jól alkalmazható a férfiak és a nők, a gazdaságilag aktívak és inaktívak, a munkaképes korúak és az idősek mortalitási különbségeinek a meghatározására (Preston and Elo, 1995; Elo et al., 2006; Koskinen and Tuija, 1994). Az egyén iskolai végzettségét a fiatalabb felnőttkor során megszerzi, a későbbiek során nem változik (Elo, 2009; Elo and Preston, 1996; Davey-Smith, 
1998; Klinger 2007: 262), a megszerzett humán tőke az élet egésze során rendelkezésre áll (Elo et al., 2006). Az iskolázottsági fokozatok szerinti halandósági egyenlőtlenségek alkalmasak a leginkább az országok (Lahelma and Valkonen, 1990), kultúrák összehasonlítására, az egészségpolitikai intézkedések előkészítésére, monitorizálására (Rychtariková and Huliková-Tesarkova, 2017). A survey típusú adatfelvételek és a haláloki anyakönyvek tapasztalatai azt jelzik, hogy az iskolázottsággal kapcsolatos információk jóval pontosabbak, mint a jövedelemre vagy a vagyonra vonatkozók (Miech et al., 2011).

Az iskolai végzettség és a halandóság közötti kapcsolat egyaránt jól dokumentált a fejlett és fejlődő (Elo et al., 2006; Stringhini et al., 2014), az alacsony és magas mortalitású (Kalediene and Petrauskiene, 2000; Kunst and Mackenbach, 1994; Shkolnikov et al., 1998), a nyugati és nem nyugati (Yang et al., 2019; JungChoi et al., 2014; Zhou et al., 2019) országokban.

Nyugat-Európában a második világháború után a jóléti állam fejlődése azt a hitet erősitette, hogy az egészséggel kapcsolatos egyenlőtlenségek fokozatosan eltűnnek. Ugyanakkor a 'Black report' és a 'Whitehall studies' és más, nagyon fejlett országokkal kapcsolatos beszámolók is rámutattak a jelentős egyenlőtlenségekre (Deboosere et al., 2009). A halandóság XX. században tapasztalt példa nélküli csökkenése ellenére a társadalmi csoportok közötti halandósági különbségek tartósnak bizonyultak (Deboosere et al., 2009; Hummer and Hernandez, 2013). A nyugat-európai országokra fókuszáló elemzés szerint az iskolázottsági csoportok közötti halandósági különbségek abszolút nagysága a 80-as és 90-es években nem változtak (Mackenbach et al., 2003). Egy negyedszázadot átölelő (1987-2011) dán elemzés a társadalmi különbségek növekedéséről számolt be a férfiaknál és a nőknél egyaránt (Brønnum-Hansen and Baadsgaard, 2012). Hasonló eredményre jutottak a belga folyamatokat elemző kutatók is, ahol ráadásul a formális iskolai végzettséggel nem rendelkező nők élettartama csökkent is (Deboosere et al., 2009). A legújabb kelet-európai trendek az egyenlőtlenségek mérséklődését, és az alacsony iskolázottságúak javuló mortalitását jelzik (Mackenbach et al., 2018), míg az Egyesült Államokból származó kutatások az egyenlőtlenségek növekedésére mutatnak rá (Ross and Mirowsky, 2003; Elo, 2009; Meara et al., 2008; Miech et al., 2011; Olshansky et al., 2012; Pappas et al., 2009; Sasson and Hayward, 2019).

A betegségstruktúra, a gazdasági és a társadalmi környezet változása ellenére a világ számos országában az egyenlőtlenségek fennmaradtak és tartósnak bizonyultak. Link és Phelan kutatópáros (Link and Phelan, 1995) arra a következtetésre jutott, hogy a társadalmi különbségek a betegségek alapvető okainak tekinthetők (Fundemental Cause of Disease). 


\section{AZ ISKOLÁZOTTSÁG ÉS A HALANDÓSÁG KAPCSOLATÁ- NAK OKAI}

Az iskolai végzettség és a mortalitás közötti erős korreláció több tényező bonyolult kapcsolatának köszönhető. A szakirodalom az iskolázottság direkt és indirekt hatását különbözteti meg (Hummer and Larisci, 2011; Luy et al., 2019; Östergren, 2017; Ross and Wu, 1995; Vandenheede et al., 2014). Az indirekt kapcsolatot hangsúlyozó megközelítések szerint az iskolázottság megteremti az egészséggel és a hosszú élettartammal kapcsolatos tényezők hozzáférési feltételeit (Luy et al., 2019). Az iskolázottság alapú egyenlőtlenségek az embereket különböző mértékű, kockázatokkal és jutalmakkal kapcsolatos pozíciók szerint rendezik sorba. Ross és Wu (1995) az erőforrások három csoportját írta le: a gazdasági erőforrásokét, amelyek elsősorban a munkaerőpiaci és anyagi biztonsággal, munkahelyi önállósággal és elégedettséggel kapcsolatosak; a szociálpszichológiai erőforrásokét, amelyek a társas támogatás (social support) és a személyes kontroll (personal control) érzetét foglalják magukban. Utóbbi ahhoz a tanult elváráshoz kötődik, hogy a történések eredményei tudatos döntésekkel, választásokkal hatékonyan befolyásolhatók, kontrollálhatók, megváltoztathatók, és nem az egyénen kívül álló külső erők, mások, a szerencse, a sors vagy a véletlen idézik elő azokat. A szerzők hangsúlyozzák, hogy a kontrollérzet hiánya fiziológiai mechanizmusokon keresztül hat az egészségre, a kontrollálhatatlanság tapasztalatai és az ezt eredményező demoralizáció az immunrendszer szupressziójával függ össze. Az oktatás növeli a kontroll érzetét, azt a felfogást alakítja, hogy az élet és az egészség a saját cselekedetek és döntések eredménye. A mechanizmus harmadik pillére az életmóddal, valamint az egészségkárositó magatartásformák iskolázottság szerint eltérő gyakoriságával függenek össze. A külsődleges erőforrások mellett Ross és Mirowsky (2003) kiemelték még az oktatásnak köszönhető, az egyéntől elválaszthatatlan inherens jellemzők fontosságát is. A tanult hatékonyság (learned effectiveness) elmélete szerint a tanulási folyamat olyan készségek, képességek fejlődését segíti elő - az elemzés, a dolgok utáni kutakodás, a kitalálás, a kommunikáció, a kitartó erőfeszítés, a figyelem -, amelyek a hatékony és sikeres problémamegoldás alapvető építőkövei. A problémamegoldó képesség növeli az élet kontrollálhatóságát, elősegíti az egyének hatékony müködését (effective agency), ösztönzi és lehetővé teszi az egészséges életmódot. Egyre több bizonyíték szól amellett, hogy a formális oktatás növeli a kognitív humán tőkét, amely elősegíti az egészséggel kapcsolatos kockázatértékelési és döntéshozatali képességeket (Baker et al., 2011). 
A JAVULÓ ISKOLÁZOTTSÁG HATÁSA AZ ÉLETTARTAMOKRA MAGYARORSZÁGON

\section{A HALANDÓSÁG TÁRSADALMI KÜLÖNBSÉGEI KELET- KÖZÉP-EURÓPÁBAN}

A kelet-európai országok halandósági egyenlőtlenségei iránt mutatkozó fokozott érdeklődést alapvetően két tényező ösztönözte, egyrészt annak megválaszolása, hogy az egalitáriánus ideológia mennyire érvényesült a halandósági viszonyokban, másrészt pedig az, hogy az 1960-as években bekövetkezett kedvezőtlen halálozási fordulat mennyire aránytalanul érintette a hátrányos helyzetű társadalmi csoportokat (Kunst, 1997). A rendszerváltozást megelőző, az államszocialista korszakból származó adatok azt mutatták, hogy a formálisan egalitárius társadalmi berendezkedésű országokban az iskolázottság szerinti halálozási különbségek elérték vagy meghaladták a nyugati országokban tapasztalt mértéket (Jasilionis et al., 2007). Az egyenlőtlenségek a nőknél legalább akkorák (Mackenbach et al., 1999), míg a férfiaknál már akkor szignifikánsan nagyobbak voltak, mint a nyugati országokban (Mackenbach et al., 1997; Krumins and Usackis, 2000). A magyar adatok a kelet-nyugat típusú összehasonlító elemzésekben gyakran előfordulnak, a nemzetközi összevetés segítségünkre lehet a folyamatok pontosabb megértésében.

A hetvenes évekről szóló elemzés, amely a skandináv országok, Magyarország, Anglia és Wales adatait hasonlítja össze, valamennyi iskolai fokozatban a 35-54 év közötti magyar férfiak és nők halálozását találta a legmagasabbnak (a diplomás magyar férfiak mortalitása magasabb volt, mint más országokban a legalacsonyabb végzettségűeké). A férfiaknál az iskolázottság és a halandóság közötti kapcsolat az ismert inverz mintázatot követte, a tanulmányban közölt ábra alapján megállapítható, hogy az abszolút különbség Magyarországon volt a legnagyobb, míg a nőknél a mintázat teljesen eltért, a diplomások standardizált arányszáma magasabb volt, mint az alacsonyabb iskolázottságúaké (Lahelma and Valkonen, 1990). Mackenbach (2018: 136-138) az „inverz egyenlőtlenséget” a magasabb iskolázottságúak ischeamiás szívbetegség, a tüdődaganatok és a közlekedési balesetek miatt bekövetkezett többlethalálozásával magyarázta.

A rendszerváltás időszakát érintő elemzés (Kunst, 1997) szerint a 30-44 év közötti, érettségivel nem rendelkező magyar férfiak rátája közel háromszorosa volt a legalább érettségivel rendelkezőkének (a finneknél ugyanaz az arány 1,7-szeres volt), a 45-59 éves férfiaknál az arány 2,2-re, míg az alacsonyabb különbségeket felvonultató finneknél 1,5-re módosult. A 45-65 év közöttiek iskolai végzettség szerinti, részleges (temporary) élettartam-különbsége nagyobb volt Észtországban, Csehországban és Magyarországon, mint az Egyesült Államokban, Franciaországban, Norvégiában és Finnországban. 
A politikai fordulat a halálozási ráták jelentős változását, a társadalmi egyenlőtlenségek drámai növekedését idézték elő a posztszovjet térség számos országában, a balti államokban (Jasilionis et al., 2007; Shkolnikov et al., 2006; Leinsalu et al., 2003) és Oroszországban (Murphy et al., 2006; Shkolnikov et al., 1998). A növekedést a magas és alacsony iskolázottságúak divergáló halandósága okozta Észtországban (Leinsalu et al., 2003), Litvániában (Kalediene and Petrauskiene, 2005) és Oroszországban is (Murphy et al., 2006). Az általánosan megfigyelt divergenciához képest Csehországban a szélső csoportok közötti különbség mérsékelt növekedése volt tapasztalható 1984-1985, valamint 1999-2000 között (Shkolnikov et al., 2006).

A hazai tanulmányok a felnőtt életkor egészének a részletes iskolázottsági csoportok szerinti elemzésére törekedtek, ellentétben a nemzetközi összehasonlító elemzésekkel. Az államszocializmus korszakában született tanulmányok a foglalkozási csoportok különbségeinek a vizsgálatára helyezték a hangsúlyt (Acsády, 1963; Klinger, 1963, 1986, 1987; Szabady 1963). Klinger (1987) a foglalkozási csoportok mérsékelt egyenlőtlenségéről számolt be - a 70-es évektől a fizikai foglalkozásúak halandóságának romlása és a szellemi foglalkozásúak javulása mellett. Majd az elsők között foglalkozott a felnőtt népesség iskolai végzettség szerinti halandósági különbségeivel (Klinger 2001, 2007). Az eredményei azt mutatták, hogy a legfeljebb 7 osztályt végzett férfiak ezer főre jutó standardizált arányszáma 1989-1990 és 2004-2005 között 29-ről 21-re, a legfeljebb szakmunkásoké 26-ról 22-re, az érettségizetteké 21-ről 18-ra, míg a diplomásoké 14-ről 12-re csökkent. A nők között az érettségizettek körében csökkent a legjelentősebben (13-ról 7-re), a diplomásoknál pedig a legkevésbé (9-ről 8-ra), ami az előbbiek kedvezőbb mortalitásához vezetett. Az alacsonyabb iskolázottságú nők halandósága is csökkent, a legfeljebb az általános iskola nyolc osztályát végzetteké 15-ről 12-re, a legfeljebb szakmunkásoké 12ről 10-re. Klinger (2001) szerint az iskolázottság és halandóság inverz kapcsolata a férfiaknál a korszakok mindegyikében jól kivehető volt, míg a nőknél a különbségek kisebbek, és a csoportok sorrendje is váltakozott. Hablicsek (2007) az iskolai végzettség szerinti mortalitási különbségeket 1986 és 2004 között a 30 éves korban várható élettartamokkal szemléltette, és a szélső iskolázottsági csoportok életkilátásainak egyre markánsabb távolodására hívta fel a figyelmet, míg a köztes csoportok halandósága nem változott. Ugyanakkor a csoportok mindegyikét figyelembe vevő népességgel súlyozott szórásnégyzet a különbségek mérséklődését mutatták a férfiaknál, a nőknél az egyenlőtlenség mértéke nem változott. Hablicsek (2007) eredményeivel egybevág, hogy az egykori szocialista tömb országaiban a halandóság változása nem azonos mértékben 
érintette az egyes szocioökonómiai csoportokat. Az alacsonyabb státusú csoportokban a halálozási ráták kevésbé javultak vagy romlottak, míg a magasabb iskolázottságúak hatékonyabban tudtak megbirkózni a fellépő kockázatokkal (Mackenbach, 2006). A különbségek növekedésével összefüggésben a közép- és kelet-európai országokban az egyenlőtlenség mértéke mindkét nemnél messze felülmúlják a nyugati országokban tapasztaltat (Mackenbach et al., 2008; Rychtaříková and Hulíková-Tesárková, 2017; Loichinger and Weber, 2016; European Union 2013). Mindazonáltal a régió nem tekinthető homogénnek, a különbségek kelet felé haladva emelkednek (Vandenheede et al., 2014). A kortárs nemzetközi összehasonlító vizsgálatokból kiderül, hogy a volt szocialista országokban a halandóság társadalmi különbségei különösen jelentősek a keringési rendszer megbetegedései okozta halálozásoknál (Mackenbach et al., 2008), az alkohollal (Mackenbach et al., 2008, 2015), valamint a dohányzással kapcsolatos halálozásoknál (Mackenbach et al., 2008).

\section{A PROBLÉMA}

Példák sokasága mutatja, hogy a magasabb iskolázottság jobb egészségi állapotot, hosszabb élettartamot biztosít az egyén számára, az oktatásba történő beruházás az egészségi állapot populációszintű javulását eredményezi a legkülönfélébb fejlettségű országokban (Baker et al., 2011; Luy et al., 2019).

Magyarországon 1990-et követően látványosan nőtt, 1990 és 2005 között megnégyszereződött a felsőoktatásban tanulók száma (Híves és Kozma, 2014). A közép-európai régió posztszocialista országaiban a felsőoktatás expanziója, a női részvétel növekedése, a programok diverzifikációja sokkal gyorsabban ment végbe, mint a nyugat-európai országokban (Dobbins and Kwiek, 2017). A felsőoktatás résztvevői és a diplomát szerzők mellett az érettségizettek aránya is jelentősen emelkedett (Híves és Kozma, 2014).

Az oktatás többféleképpen befolyásolhatja a népesség egészének a halandósági szintjét. Az iskolázottság javulása a magas iskolázottságú népesség arányának a növekedését és az alacsony iskolázottságúak csökkenését jelenti, ami változatlan mortalitási viszonyok mellett is - a struktúra változásának köszönhetően - növeli a várható élettartamot. Ugyanakkor lehetséges az is, hogy az iskolázottsági csoportokon belül következnek be a változások, amelyek hatással lehetnek az iskolázottsági különbségeikre. Például az iskolai végzettség gyors emelkedésével kiválhatnak a jobb egészségi állapottal rendelkezők, a hátramaradók összetétele ezáltal kedvezőtlenebbé válik, mortalitásuk rom- 
lik, az alsó és felső kategóriák különbsége pedig növekszik (Shkolnikov et al., 2006). Mostanáig kevés figyelmet kapott Magyarországon, hogy a népesség iskolázottsági struktúrájának változása milyen mértékben eredményezi a várható élettartam növekedését az iskolázottsági csoportok változó halandósága mellett.

\section{ADATOK}

Az elemzésben szereplő adatok két, egymástól független adatforrásból származnak (unlinked cross-sectional data). A népességadatok az 1990-es és 2011es népszámlálások eszmei időpontjának állapotát tükrözik. A halálozási adatok a Központi Statisztikai Hivatal (KSH) népességregiszteréből (demográfia táblázó, demo) kerültek lekérdezésre. Az iskolázottság szerinti csoportok kialakitásánál a részletesebb kategorizálásra törekedtem, a túlságosan leegyszerűsített, kevés számú csoportot tartalmazó megközelítések hajlamosak a társadalmon belüli különbségeket elmaszkírozni (Hummer and Hernandez, 2013). Az elemzés csak a 25 éves és idősebb felnőtt népességre terjed ki, többségükről feltételezhető, hogy iskolai életpályájuk már lezárult vagy a későbbiekben már kevéssé fog változni.

Olyan iskolázottsági csoportok szerinti elemzés megvalósitása volt a cél, amelyek mindkét időpontban, a vizsgált életkorok mindegyikére tartalmaz kockázati népességet. Ez az elvárás egyes csoportok összevonását tette szükségessé. A szakmunkás iskolai végzettséget a hatvanas évek elején vezették be Magyarországon. 1990-ben az érettségi nélkül középfokú végzettséggel rendelkező népesség tagjai közül senki sem töltötte még be az ötvenedik életévét, miközben a halálozási regiszterben több ilyen haláleset is előfordult. Az adatbázisban szereplő adatok arra utalnak, hogy a valósnál magasabb iskolai végzettség rögzítésére került sor, emiatt a nyolc osztályt, illetve a szakmunkásképzőt, szakiskolát végzettek szétválasztása a kilencvenes években nem problémamentes. A nyolc osztály alatti végzettségüek heterogén demográfiai viselkedésű csoportokat foglalnak magukban, mivel a nyolc osztályos alapfokú végzettség csak 1945-től van jelen a magyar iskolarendszerben, korábban hat, azt megelőzően a négy osztály felelt meg ennek (Hablicsek, 2007). Csak az érettségizettek és a diplomások esetében beszélhetünk egyértelműen definiálható csoportokról. Velük kapcsolatban az időskorúak alacsony száma okoz nehézséget (1. táblázat).

${ }^{1}$ http://www.ksh.hu/nepszamlalas/tablak_iskolazottsag 
A részletes iskolázottsági csoportok korévekre meghatározott mortalitási rátái különösen az idősebb életkorokban ingadozóak. Az adatok stabilitását jelentősen segíti, ha a halálesetek és a kockázatnak kitett népesség számát ötéves korcsoportokba összevonjuk. A probléma további kezeléséhez három év halálozásainak együttes elemzésére került sor, amelyek így a cenzust megelőző és azt követő évek adatait tartalmazzák, ezáltal a halálozási ráták nevezőjében a cenzusnépesség háromszorosa szerepel, feltételezve, hogy a népesség eloszlása a cenzust megelőző és azt követő évben is azonos volt. Az elemzésben szereplő csoportosítás megfelel a korábbi hazai elemzések gyakorlatának (Hablicsek, 2007; Klinger 2001, 2007; Bálint és Németh, 2016), de eltér a napjainkban általánosan elfogadott, az Eurostat², az OECD (Murtin et al., 2017) és mások (Loichinger and Weber, 2016; Luy et al., 2019; Vandenheede et al., 2014) által is alkalmazott alacsony, közepes és magas (ISCED-97-skála: 0-2, 3-4, 5-6) csoportokétól, emiatt az eredményeink a diplomások kivételével nem hasonlíthatók össze ezen elemzések eredményeivel. Részletezettebb elemzés pedig csak szűkebb életkorszegmensre valósitható meg (Daróczi, 2004).

Az elemzés számára problémát jelentett, hogy az iskolázottságra vonatkozó adatok a 2011-es cenzus körüli években hiányosak voltak. 2010 és 2012 között 38536225 éves és annál idősebb ember halt meg Magyarországon, közülük 27 408-nak (7,1\%) az iskolai végzettségéről nem állt rendelkezésre információ. Az adathiány mértéke 2002-ig gyakorlatilag elenyésző volt, a felnőtt férfiak mindössze 0,4, a nők 0,2\%-át érintette. A rákövetkező évben mindkét nemnél 2,0\%-ra nőtt az arányuk. A hiányzó információjú esetek aránya 2012-ben már 8\% körül alakult. Ugyanakkor az adathiány a vizsgált három évben sem nemenként (7,1-7,2\%), sem korcsoportonként nem tért el jelentősen, a jelzett arányok szerint alakultak. Regionálisan azonban jelentős különbségek mutatkoztak, Közép-Magyarországon az ismeretlen iskolázottságú halálesetek aránya az összes haláleset közel ötödét tette ki (a férfiaknál 19,5, a nőknél 19,1\%-át), míg Közép-Dunántúlon már jóval kisebb volt az ismeretlen iskolázottságú esetek aránya (4,6 és 3,8\%), a fennmaradó régiókban pedig még ennél is alacsonyabb adathiány tapasztalható (a férfiaknál 1,6-3,0\%, a nőknél 1,4-2,6\%). A tanulmány jellegénél fogva az ismeretlen végzettséggel rendelkező esetek nem hagyhatók figyelmen kívül, mert ezzel alábecsülnénk a halálozás szintjét, és túlbecsülnénk a várható élettartamokat. A halálesetek pótlására többféle eljárást alkalmaztunk. A legközelebbi szomszéd ( $k$-nearest neighbour), a többszörös láncegyenletek (chained equation/MICE), és az ismert halálesetek korcsoportos arányai szerint szétosz-

${ }^{2}$ https://ec.europa.eu/eurostat/web/products-datasets/-/demo_mlexpecedu 
tott halálesetek hasonló eredményre vezettek, így az utóbbi egyszerübb, és mások által könnyen ellenőrizhető eljárás eredményeire támaszkodok. A lakcímmel nem rendelkező, a hajléktalan, a külföldi, és az ismeretlen lakóhelyű halálesetek (1989 és 1991 között 3181 fő, ebből 2203 férfi, 978 nő; 2010 és 2012 között 3203 fő, ebből 2319 férfi, 884 nő) lakóhelyeként a halál bekövetkezésének esethelyét vettem figyelembe.

\section{MÓDSZER}

Az elemzéshez rövidített halandósági táblák létrehozására került sor a 25-től a 90 éves és afeletti életkorig, nemek szerint Közép-Magyarország és a vidéki régiók együttesére (továbbiakban: vidék). A korspecifikus halálozási adatokat egydimenziójú P-splines-módszerrel simítottam (Camarda, 2012). Az élettartamban kifejezhető különbség a nyers és a simított ráták között csekély (lásd a 2. táblázatot és a mellékletben közölt részletes régiós eredményeket), a vizualizációban ugyanakkor számottevő mértékben segíti az értelmezést (1-2. ábrák).

A tanulmány célja, hogy a magyar felnőtt népesség 25 éves korban várható élettartamának 1990 (t1) és 2011 (t2) közötti időszakban bekövetkező változását felbonthassuk az iskolázottságspecifikus halálozási (M-hatás) és a népesség iskolázottsági struktúrájában bekövetkező populációs hatás (P-hatás) hozzájárulásaira (Shkolnikov et al., 2006). A mortalitási és a populációs hatások egyidejű szétválasztása nem egyszerű, mivel nagyon bonyolult módon összefüggnek egymással. Belátható, ha az iskolázottság-specifikus halálozás megváltozik, a túlélés esélyei bizonyos csoportok előnyére vagy hátrányára módosulnak, megváltozik az egyes csoportok struktúrája. Az előbbihez hasonlóan, a népesség iskolázottsági struktúrájának a változása befolyásolja a halálozási szintet, mivel az iskolázottság-specifikus alpopulációk kockázati összetétele változik meg, amikor kevésbé iskolázott, magasabb halálozási kockázatú egyének nagyobb hányada magasabb iskolázottsági szintre lép. A két időpont között mindkét változás történhet egyidejűleg, eltérő nagysággal, ami megnehezíti a hatások szétválasztását.

Helyettesítési dekompozíciós technikát alkalmaztunk (Andreev et al., 2002; Jdanov et al., 2017), amely az M- és P-hatásokat t1- és t2-időpontok átlagában határozza meg. A módszer alapvetően az életkor-specifikus halálozási arányok egyik vektorának elemeit lépésenként helyettesíti egy másik vektor megfelelő elemeivel (Andreev et al., 2002). Az eljárás előnye, hogy a helyettesítés minden iskolázottsági alcsoportra külön elvégezhető, ami lehetővé teszi az 
M-hatás felosztását az iskolázottsági csoportspecifikus halandóság változásaihoz (Shkolnikov et al., 2006). Elemzéseinkhez az Andreev és Shkolnikov (2012) által készitett MS Excel makrót használtuk. A számításokhoz Andreev és Shkolnikov (2012) által készített MS Excel makrót használtam.

\section{DESKRIPTÍV EREDMÉNYEK}

A 25 éves és annál idősebb népesség iskolai végzettség szerinti eloszlását az 1. táblázat ismerteti korcsoportok, nemek és területi egységek szerinti bontásban. A vizsgált időszakban drámaian megváltozott a népesség összetétele, jelentősen csökkent a nyolc osztályt el nem végzettek és ezzel párhuzamosan nőtt az érettségizettek és a diplomások aránya, a változás nagyságrendileg hasonló volt a két nemnél. A legnépesebb csoportot az alapfokú és szakmunkás végzettségü férfiak és a nők alkották, számuk 130-140 ezerrel nőtt, a csoport össznépességen belüli aránya nem változott (1990-ben 46,4\%, 2011-ben 47,0\%). A rendszerváltozást követő két évtized alatt megduplázódott a diplomások száma (688 ezerről 1,38 millióra). Arányuk 10,1-ről 19\%-ra nőtt, ami azonban még elmaradt az OECD átlagától (Híves és Kozma, 2014). Az érettségizettek száma 870 ezerrel haladta meg az 1990-es értéket. A változások egyik fontos jellemzője, hogy a nők iskolázottabbá váltak, az érettségizettek és a diplomások aránya is magasabb körükben, mint a férfiaknál.

A népesség iskolázottsági struktúrájának időbeli változása azt jelenti, hogy az idősebb, alacsonyabb iskolázottságú kohorszokat magasabb iskolázottságú, fiatalabb kohorszok váltják fel. A folyamatot a közép- és felsőfokú oktatáshoz való könnyebb hozzáférés, a magasabb iskolai végzettség iránt megnövekedett igény segítette elő. 2011-ben például a 25-44 év közötti férfiak közel felének (49,7\%), míg a hasonló korú nők 65,6\%-ának volt érettségije vagy diplomája, a 65 éves és idősebbeknél viszont az arányuk ennél jóval alacsonyabb (38,7 és $27,6 \%)$.

Területi összehasonlításban éles a törésvonal a fővárosi régió és a vidéki régiók között (lásd a részletes területi adatokat a szöveg végén). A fővárosiak iskolázottabbak, mint a vidéki régiókban élők. A struktúrában történt változás a regionális különbségek növekedése mellett zajlott le. A legalább érettségivel rendelkező férfiak aránya 38,6-ről 58,7\%-ra nőtt 2011-re Közép-Magyarországon és 28,2-ről 44,2\%-ra a vidéki régiókban. 


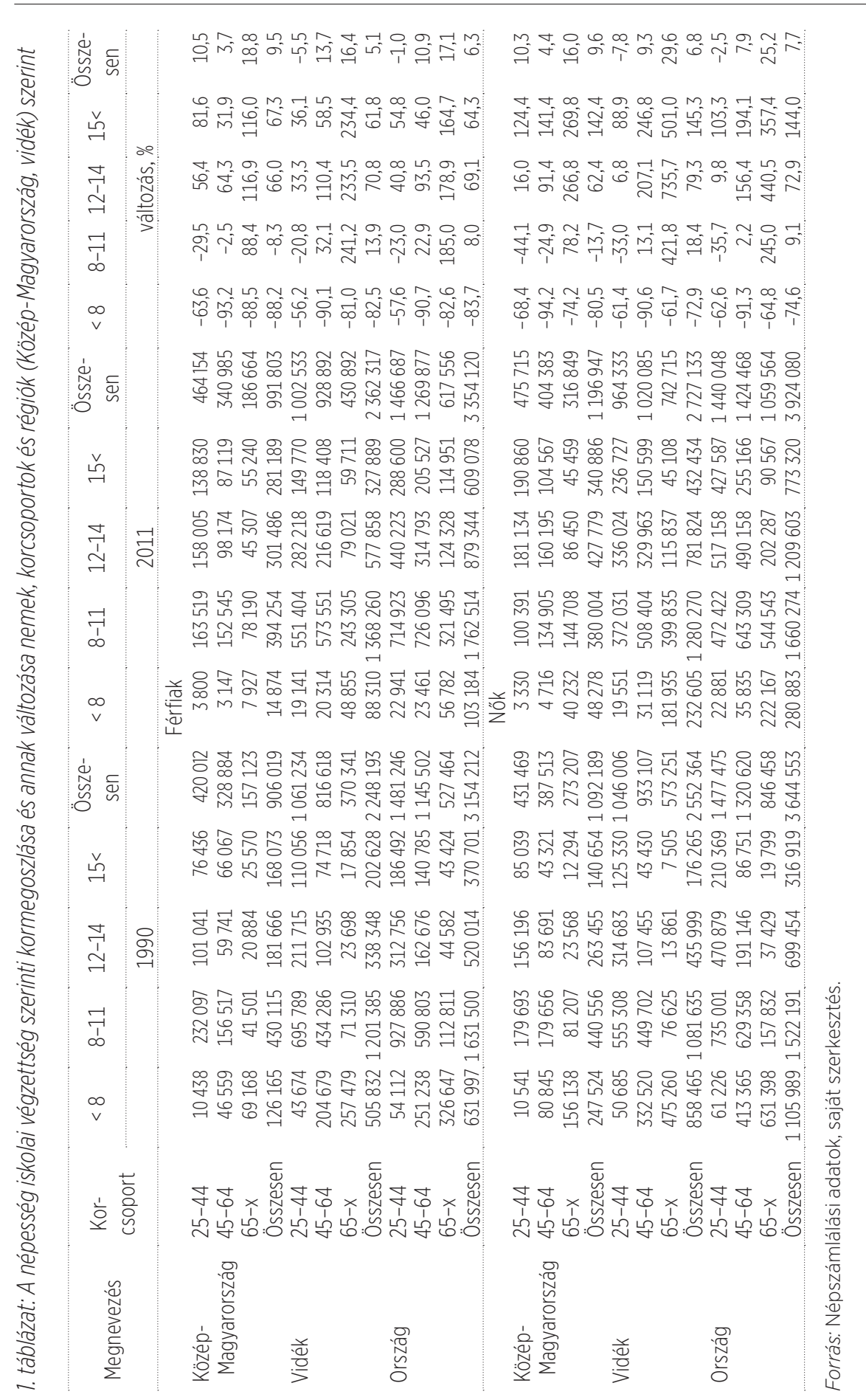




\section{A KORSPECIFIKUS HALÁLOZÁSI RÁTÁK NEMEK SZERINT 1990 ÉS 2011 KÖRÜL}

A kilencvenes évek elején az iskolázottsági csoportok szerinti különbségek a férfiaknál 50 éves korig az iskolázottsági hierarchia sorrendjét követték, és a nyolc osztályt végzettek kivételével meg is őrizték azt (1. ábra). A későbbi életkorokban a legalacsonyabb iskolázottságúak halandósága keresztezte az érettségizettekét, a legidősebb életkorokban pedig a diplomások szintjére esett vissza. Hablicsek (2007) az idősebb életkorszegmens adatait használhatatlannak ítélte, és helyettük a középkorúak továbbvezetett adataira támaszkodott tanulmányában. A jelenséget azzal magyarázta, hogy az alapfokú iskolai végzettség nem minden születési évjáratnál volt nyolc év, az idősebb népességénél hat, illetve négy év, és ennek a statisztikai számbavétele a két adatforrásban következetlen (Hablicsek, 2007). Ebből az következhet, hogy a nyolc osztály alattiak halálozási rátáinak javulása a csoport összetételének, a nyolc osztály alatti, de alapfokú iskolai végzettséggel rendelkezőknek köszönhető. Ugyanakkor előfordulhat az is, hogy a hozzátartozók az általuk ismert alapfokú végzettségre (általános iskola nyolc osztály) léptették elő elhunyt családtagjukat, csökkentve a nyolc osztály alatti végzettséggel, és növelve az annál magasabb végzettséghez tartozó haláleseteket, ami az érintett időskori ráták bizonytalanságát eredményezhette.

A 2011 körüli halálozási görbék már a várakozásnak megfelelő egyenlőtlenséget mutatták. Jól kivehetők a befejezett iskolai fokozatok szerinti szintkülönbségek. A 40-60 év közötti, legfeljebb szakmunkás végzettségűeknél figyelhető meg markáns halandósági többlet, míg a legalacsonyabb végzettségüeknél a felnőttkor korai szakaszán figyelhető meg extrém mértékű, majd az életkorral csökkenő magasabb szintű halálozás (1. ábra). Az ábrák a régiók mindegyikében azt mutatják, hogy a státuskülönbségek az életkor előrehaladtával csökkennek (status leveling), ami az időskori biológiai folyamatok jelentőségét hangsúlyozzák a társadalmi tényezőkkel szemben (Hoffmann, 2008). 
1. ábra: A férfiak iskolai végzettség szerinti halálozási görbéi Közép-Magyarországon, a vidéki régiókban és együtt
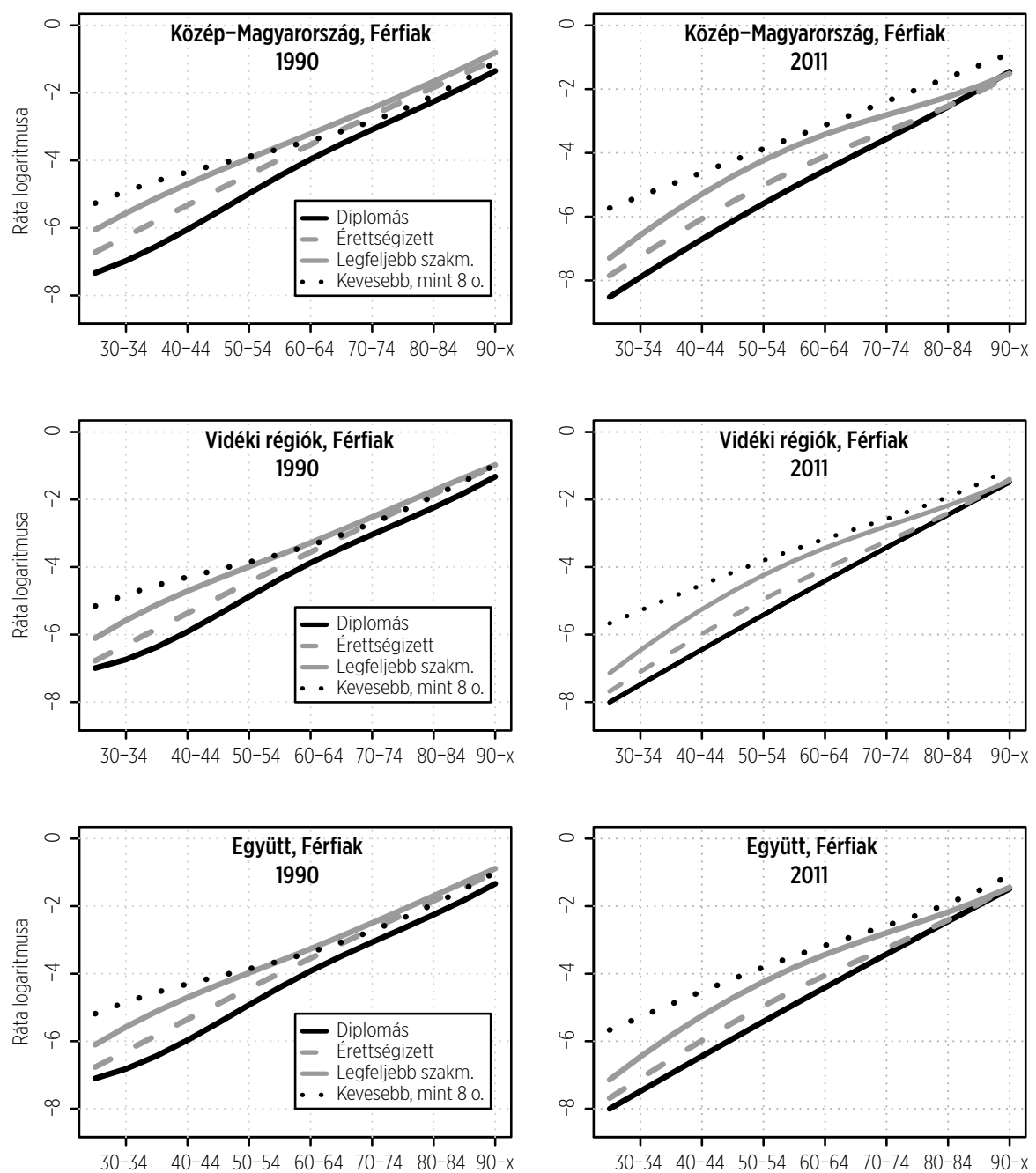

A nők rátái a Hablicsek által jelzett nagyjából 60 éves korig megbízhatónak tűnnek, a férfiaktól eltérően itt az idősebb korú érettségizett nők rátái problematikusak (2. ábra). A férfiakhoz hasonlóan a 2011 körüli évek halálozási görbéi a várakozásnak megfelelően, az iskolázottsággal csökkenő halálozási különbségeket mutatnak területi hovatartozástól függetlenül. 
2. ábra: A nök iskolai végzettség szerinti halálozási görbéi Közép-Magyarországon, a vidéki régiókban és együtt
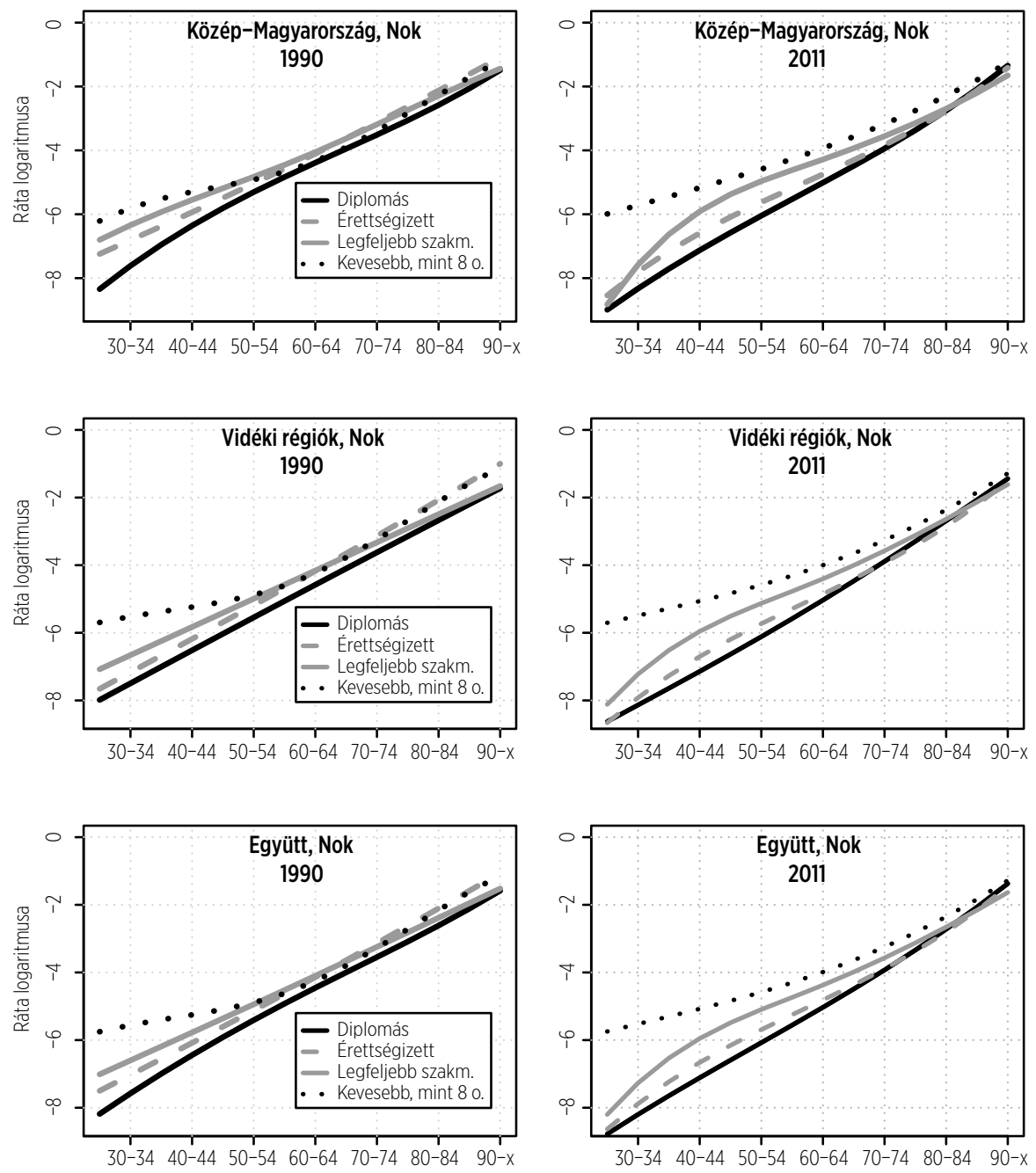


\section{A VÁRHATÓ ÉLETTARTAMOK ISKOLAI VÉGZETTSÉG SZERINT}

A népesség egészének halálozási rátája felfogható a különböző iskolázottsági csoportok halálozási rátáinak súlyozott átlagaként, ezért az így kapott várható élettartamoknak jól kell közelíteniük a hivatalos adatközlésekben megjelent, valamint a népességregiszter adatai alapján számolt regionális és országos élettartamokat. A KSH által közölt rövidített halandósági táblákból származó adatok szerint a 25 éves életkorban várható átlagos élettartam 1990-ben 42,12 év volt a férfiaknál és 50,26 év a nőknél (Központi Statisztikai Hivatal [KSH], 1995: 146), az 1989-1991-re vonatkozó számításaink ezzel közel azonosak voltak (42,13 és 50,29 év). A 2011 körüli élettartamok is csak kismértékű eltérést mutattak a hivatalosan közölt adatokhoz képest, 2011-ben a 25 éves korban várható élettartam a férfiaknál 46,94, a nőknél 54,30 év volt (KSH, 2012), míg a 20102012-re becsült értékek ettől szinte nem tértek el (46,97 és 54,31 év).

Az iskolázottság szerinti halandósági különbségek a férfiaknál a várakozásnak megfelelő sorrendet jelezték a vizsgált időszakok mindegyikében, míg a nőknél a különbségek kisebbek voltak, és nem minden esetben követték az iskolai fokozatok sorrendjét (2. táblázat). A vizsgált időszakban a férfiak 25 éves életkorban várható élettartama 4,8, a nőké 3,9 évvel növekedett. Az élettartam-változás eltérően érintette az egyes csoportokat: az alacsony iskolázottságú, nyolc osztállyal nem rendelkező, vidéki férfiak életkilátásai alig változtak (+0,55 év), míg a hasonló iskolázottságú nőké csökkent (-1,2 év) a korábbi időszakhoz képest (2. táblázat).

A diplomás nők élettartama 54,3-ről 57,2 évre, a férfiaké 49,3-ről 53,9 évre, mintegy 4,6 évvel nőtt. Az érettségizetteknél mutatkozott a legnagyobb javulás (6,5-6,6 év), bár ennek a mértéke a nőknél bizonyosan kisebb lehetett az 1990-es ráták feltételezett alulbecslése miatt. A csoporthoz tartozó nők várható élettartama (56,6 év) alig több mint fél évvel maradt el a diplomás társaikétól (57,2 év). A felzárkózásuk egyaránt megfigyelhető volt vidéken és KözépMagyarországon is. A konvergencia tehát nem tűnik műterméknek, valószínűleg az élenjáró, mintaadó csoport szokásainak, egészségmagatartásának az átvétele nagyban segithette a felzárkózást, de ezzel együtt elképzelhető az is, hogy a felnőttkorban diplomát szerzők szokásaikban, életmódjukban erősebben kötődhettek a korábbi csoporthoz, ami a diplomások javulását fékezhette.

A legnépesebb csoport, a legfeljebb szakmunkás iskolai végzettséggel rendelkező férfiak (4,4 év) és nők élettartam-nyeresége (3,1 év) a diplomásokétól alig tért el. Esetükben nem került sor felzárkózásra a legjobb gyakorlatot hordozó csoporthoz képest. 
2. táblázat: A 25 éves életkorban várható élettartam iskolai végzettség és nemek szerint Közép-Magyarországon, a vidéki régiókban és országosan 1990 és 2011 körül

(év)

\begin{tabular}{|c|c|c|c|c|c|c|}
\hline Régiók & Időszak & $<8$ & $8-11$ & $12-14$ & $15<$ & Együtt \\
\hline \multicolumn{7}{|c|}{ Férfiak } \\
\hline \multirow[t]{3}{*}{ Közép-Magyarország } & 1989-1991 & 39,13 & 39,80 & 44,36 & 49,67 & 42,76 \\
\hline & $2010-2012$ & 38,68 & 44,78 & 51,69 & 54,56 & 48,48 \\
\hline & különbség & $-0,45$ & 4,98 & 7,34 & 4,89 & 5,71 \\
\hline \multirow[t]{3}{*}{ Vidéki régiók } & 1989-1991 & 38,01 & 40,39 & 44,64 & 48,84 & 41,89 \\
\hline & 2010-2012 & 38,86 & 44,56 & 50,66 & 53,26 & 46,40 \\
\hline & különbség & 0,85 & 4,17 & 6,02 & 4,42 & 4,51 \\
\hline \multirow[t]{3}{*}{ Ország } & 1989-1991 & 38,23 & 40,20 & 44,53 & 49,25 & 42,13 \\
\hline & $2010-2012$ & 38,78 & 44,61 & 51,02 & 53,86 & 46,97 \\
\hline & különbség & 0,55 & 4,42 & 6,49 & 4,61 & 4,84 \\
\hline \multicolumn{7}{|c|}{ Nők } \\
\hline \multirow[t]{3}{*}{ Közép-Magyarország } & 1989-1991 & 49,30 & 49,16 & 49,68 & 53,65 & 50,35 \\
\hline & $2010-2012$ & 46,96 & 53,15 & 56,08 & 57,28 & 54,79 \\
\hline & különbség & $-2,35$ & 3,99 & 6,40 & 3,63 & 4,43 \\
\hline \multirow[t]{3}{*}{ Vidéki régiók } & 1989-1991 & 47,67 & 51,26 & 50,27 & 55,24 & 50,28 \\
\hline & $2010-2012$ & 46,85 & 53,47 & 57,09 & 57,15 & 54,02 \\
\hline & különbség & $-0,82$ & 2,21 & 6,82 & 1,92 & 3,74 \\
\hline \multirow[t]{3}{*}{ Ország } & 1989-1991 & 48,00 & 50,33 & 50,07 & 54,25 & 50,31 \\
\hline & $2010-2012$ & 46,85 & 53,43 & 56,63 & 57,22 & 54,25 \\
\hline & különbség & $-1,15$ & 3,10 & 6,55 & 2,97 & 3,94 \\
\hline
\end{tabular}

A férfiak és a nők közötti élettartam-különbség kismértékben (0,6 évvel) mérséklődött a vizsgált két évtized alatt. Az azonos végzettségű férfiak és nők közötti különbségeknem konstansak, az eltérés az iskolázottság növekedésével csökkenő (Shkolnikov et al., 1998). A hazai adatok ezt a legalacsonyabb iskolázottságúak kivételével alá is támasztják. A diplomás férfiak és nők különbsége 2011-ben 3,1 év (korábban 5,0 év), az érettségizetteké 5,5 év (korábban 5,6 év), a legfeljebb szakmunkásoké 8,8 év (1990-es évek elején 10,1 év), míg a nyolcnál kevesebb osztályt végzetteké 8,1 év (ezt megelőzően 9,8 év) volt. A nemek közötti különbséget jól szemlélteti az, hogy a diplomás férfiak várható élettartama a legfeljebb szakmunkás végzettségü nőkének felelt meg (3. ábra). 
3. ábra: A 25 éves életkorban várható élettartam iskolai végzettség és nemek szerint Közép-Magyarországon, a vidéki régiókban és országosan
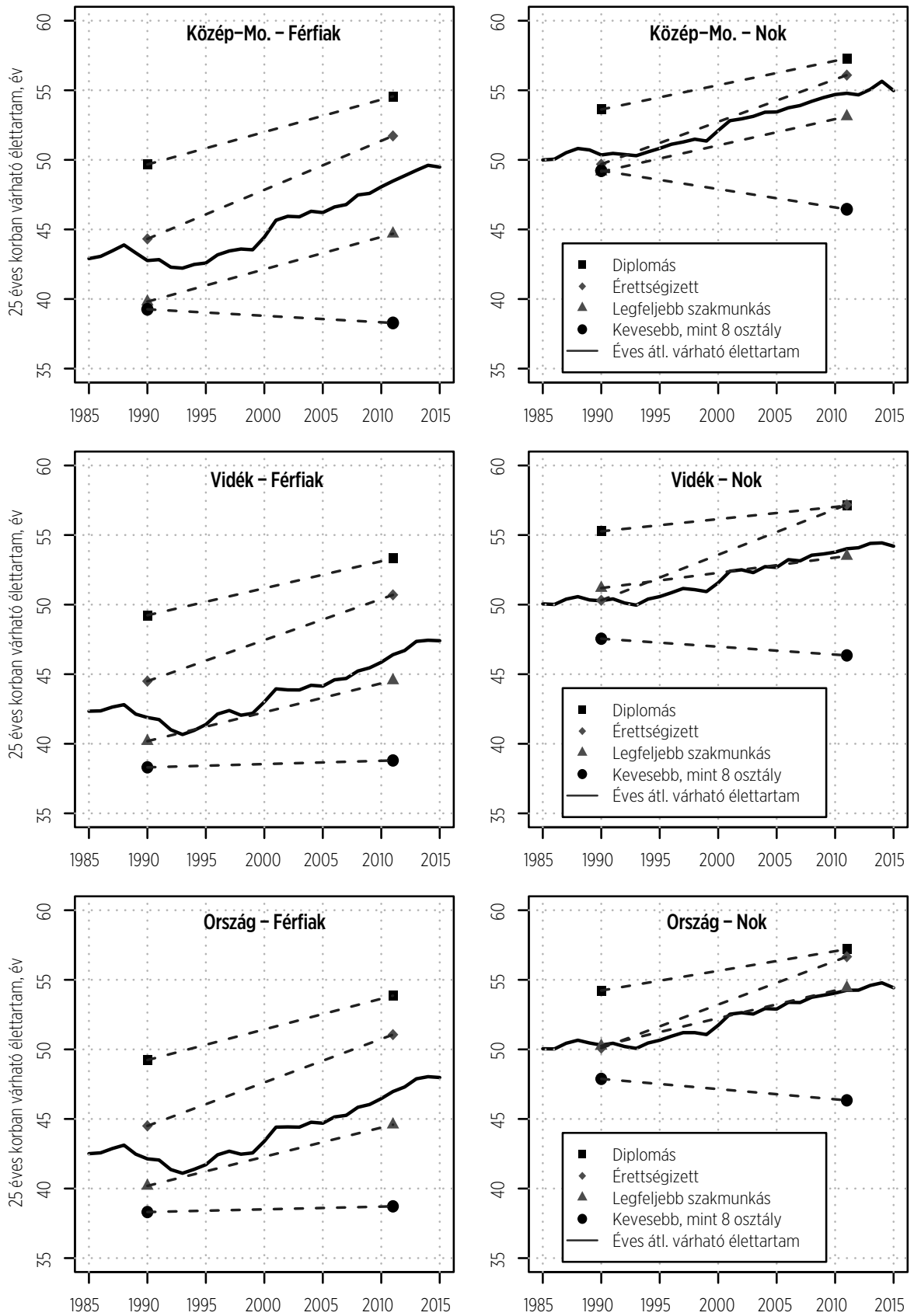
Ugyancsak jól ismert, hogy a halandóság és az iskolai végzettség közötti erős kapcsolat nemenként eltér, a különbségek jelentősebbek a férfiaknál, mint a nőknél (Koskinen and Martelin, 1994; Klinger, 2001). A legmagasabb és a legalacsonyabb iskolázottsági csoport közötti különbség - amely szemléletes és gyakran használt, de a köztes csoportok mellőzése miatt erősen megkérdőjelezhető mutató - a férfiaknál 11,0-ről 15,1 évre, a nőknél 6,3-ről 10,4 évre növekedett. Több kutatás azt jelzi, hogy a társadalmi csoportok közötti különbség a felnőtt népesség esetében valamennyi életkorban megfigyelhető (Luy et al. 2011; Valkonen 2006; Kunst 1998). Eredményeink mindezt a férfiaknál maradéktalanul alátámasztják, míg a nőknél az érettségivel rendelkező és az alatti csoportok életkor szerinti megosztottsága a leginkább kivehető.

\section{A DEKOMPONÁLÁS EREDMÉNYEI}

A 3. táblázat összegzi a mortalitásváltozásnak és az összetétel-változásnak a felnőtt élettartamra gyakorolt hatását. Mindkét nemnél a mortalitásváltozás hatása volt a jelentősebb, országosan a férfiaknál a javulás több mint kétharmada (70,1\%-a, 3,4 év), a nőknél ennél valamivel kisebb hányadát lehetett a halandóság javulásának (61,3\%-a, 2,4 év) tulajdonítani. A struktúraváltozás abszolút nagysága kevéssé tért el nemek szerint, a nőknél 1,7 év (44,5\%), a férfiaknál 1,45 év (31,2\%) volt.

Közép-Magyarországon az élettartam javulása a férfiaknál és a nőknél is számottevőbb volt, mint a vidéki régiókban. Arányaiban azonban a populációs hatás mindkét nemnél a változás egyharmadáért felelt (32,3 és 32,7\%), míg a vidéki régiókban a férfiak élettartam-javulásához arányaiban kisebb (1,0 év, 24,0\%), a nőknél nagyobb (1,7 év, 45,7\%) mértékben járult hozzá.

A férfiaknál a mortalitás javulása a legfeljebb szakmunkás végzettségủekhez kötődött (2,4 év), a nőknél a legfeljebb szakmunkások (1,1 év) mellett az érettségizettek mortalitásának a változása is (1,0 év) is közel hasonló mértékü hozzájárulással bírt. Érdekesség, hogy a diplomások halandóságának változása mindkét nemnél viszonylag kis jelentőségü, miközben a nyolcnál kevesebb osztályt végzett férfiaké negatív előjelű volt. 
3. táblázat: A különböző iskolázottsági csoportok halandóság-, valamint az iskolázottsági struktúra változásának hozzájárulásai a népesség várható élettartam-változásához mindkét nem esetében

\begin{tabular}{|c|c|c|c|c|c|c|c|}
\hline \multirow[b]{2}{*}{ Régiók } & \multicolumn{5}{|c|}{ Mortalitási hatás } & \multirow[b]{2}{*}{$\begin{array}{l}\text { Populációs } \\
\text { hatás }\end{array}$} & \multirow{2}{*}{$\begin{array}{c}\text { Teljes } \\
\text { változás } \\
\text { 1989-1991/ } \\
\text { 2010-2012 } \\
\text { között }\end{array}$} \\
\hline & $<8$ & $8-11$ & $12-14$ & $15<$ & együtt & & \\
\hline \multicolumn{8}{|c|}{ Férfiak } \\
\hline Közép-Magyarország & $-0,61$ & 2,46 & 1,30 & 0,70 & 3,85 & 1,84 & 5,69 \\
\hline Vidéki régiók & $-0,18$ & 2,32 & 0,80 & 0,33 & 3,27 & 1,03 & 4,30 \\
\hline Együtt & $-0,28$ & 2,38 & 0,90 & 0,40 & 3,40 & 1,45 & 4,85 \\
\hline \multicolumn{8}{|c|}{ Nök } \\
\hline Közép-Magyarország & $-0,39$ & 1,43 & 1,42 & 0,47 & 2,93 & 1,42 & 4,34 \\
\hline Vidéki régiók & 0,24 & 0,83 & 0,80 & 0,16 & 2,03 & 1,70 & 3,72 \\
\hline Együtt & 0,05 & 1,10 & 0,98 & 0,26 & 2,39 & 1,50 & 3,90 \\
\hline
\end{tabular}

\section{ÉRTELMEZÉS}

Mielőtt értelmeznénk az eredményeket, fontos utalni a tanulmány korlátaira. Az iskolai végzettség szerinti korspecifikus halálozási ráták két különböző, egymástól független adatforrás információin alapulnak. A ráták számlálójában szereplő halálozási adatok a népmozgalmi regiszterből, míg a nevezőben szereplő népességadatok a népszámlálás adatállományából származnak. A számláló-nevező torzítás (nominator-denominator bias) gyakori kísérőjelensége a hasonló vizsgálatoknak, ami komolyan befolyásolhatja az egyenlőtlenség nagyságát és tendenciáit (Vandenheede et al., 2014).

Gyakori probléma az ún. posztumusz elöléptetés, amikor a halotti anyakönyvben szereplő iskolai végzettség magasabb a ténylegesen megszerzettnél (Shkolnikov et al., 2006). Az Egyesült Államokban a leggyakoribb hiba, hogy középiskolai végzettséget tüntetnek fel, miközben az elhunyt tényleges iskolai végzettsége ennél gyakran alacsonyabb (Sorlie and Johnson, 1996; Rostron et al., 2010).

A besorolás okozta torzítás hazai nagyságával kapcsolatban nincsenek pontos ismereteink, de valószínűnek látszik, hogy a kilencvenes évek elején az idősebb, érettségizett nők magas halálozását hasonló problémák okozhatták. A téves besorolás legalább két csoportot érintett, a csoportok eltérő népességnagysága miatt a torzítás nem könnyen tűnik fel és detektálható a nagyobb népességü csoportban. 
Az elemzés ugyancsak fontos limitációja, hogy az iskolai végzettség az elemzés második periódusában a halálesetek jelentős hányadában ismeretlen volt. 2003-at megelőzően az adathiány évente mindössze 0,1-0,8\%-ot tett ki, ezt követően az arányuk folyamatosan növekedett. Az adathiány mértéke nemenként és korcsoportonként sem tért el jelentősen, többségük Közép-Magyarországon (a fővárosban) fordult elő.

Az iskolázottság fundamentális oka a halandóságnak, több példa is azt igazolja, hogy a szocioökonómiai pozíció dimenzióinak mindegyike önálló magyarázóerővel bír, és rajtuk kívül még számos olyan emberi tulajdonság sorakoztatható fel, amelyeket az elemzésünkben nem vettünk figyelembe. Első megközelítésben azt mondhatnánk, hogy az iskolázottság hatását túlhangsúlyozzuk. Ennek ellenére a kérdés tanulmányozása több szempontból is releváns. Valkonen (2006) szerint demográfiai nézőpontból a társadalmi-gazdasági különbségek a népesség alcsoportjait jobban elkülönítik más különbségekhez képest. A halandóság társadalmi egyenlőtlenségeinek vizsgálata hozzájárul a halandósági szintek és tényezőinek jobb megértéséhez. Társadalom- és egészségpolitikai szempontból az egyenlőtlenségek nyomon követése pedig azért fontos, mert általuk információt nyerhetünk az egészség és a jóllét egyenlőtlenségeivel kapcsolatban.

A modern társadalmakhoz hasonlóan Magyarországon is az iskolai végzettség tekinthető a különböző társadalmi-foglalkozási pozíciókba való bejutás egyik legfontosabb tényezőjének (Vastagh, 2015). Jól dokumentált, hogy az iskolai végzettség növekedésével javulnak a foglalkoztatási esélyek, csökken a munkanélküliség (Nagy, 2000) és a szegénység kockázata (Kapitány és Spéder, 2004), növekszik a kereset (Kézdi, 2004). Magyarországon nemzetközi összehasonlításban is nagyon erős az iskolázottságnak a munkaerőpiaci, illetve foglalkozási pozícióra gyakorolt hatása (Kolosi és Keller, 2012).

Magyarországon - a világ szinte bármely országához hasonlóan - a magasabb iskolázottságúak hosszabb életre számíthatnak, mint a kevésbé iskolázottak. Az átmenet megrázkódtatásai az alacsony iskolai végzettségüeket érintette a leginkább (Hablicsek, 2007; Kovács, 2007). Az újabb adatok az élettartam-különbség további növekedését jelzik a szélső csoportok között. A formális iskolai végzettséggel nem rendelkezők és a diplomások közötti élettartam-különbség 2011-ben a férfiaknál meghaladta a 15, a nőknél a 10 évet. A különbség növekedése az alacsony iskolázottságúak romló, illetve stagnáló életkilátásaival függ össze.

A nemzetközi (Murtin et al., 2017; Mackenbach, 2006) és a hazai tapasztalatokkal (Hablicsek, 2007; Kovács és Bálint, 2014; Daróczi, 2004) egybecsengően a szocioökonómiai státus szerinti különbségek (a periódusok mindegyikében) kisebbek voltak a nőknél, mint a férfiaknál. 
A köztes csoportok élettartama eltérően alakult. A hazai folyamatok fontos jellemzője az érettségizettek, különösen az érettségivel rendelkező nők látványos felzárkózása a diplomásokhoz, miközben a legfeljebb szakmunkás végzettségűeknél megmaradt a két évtizeddel korábban is meglévő, jelentős hátrány.

A változás értelmezésekor, az általános mortalitás javulásának a megértéséhez figyelembe kell venni azt a tényt, hogy az elemzett időszakban a népesség iskolázottsági szintje javult, és az iskolázottsági alcsoportok mérete változott. Így az iskolázottsági szint általános emelkedésének következményeként feltételezhető, hogy az alacsonyabb iskolai végzettségűek egyre kisebb, a foglalkozási, kereseti és más, az egészséggel kapcsolatos szempontból egyre marginalizáltabb csoportot alkotnak (Brønnum-Hansen and Baadsgaard, 2007). Ez magyarázhatja a (többségében) formális iskolai végzettséggel nem rendelkező, nyolcnál osztály alatti nők csökkenő élettartamát. Felmerülhet, hogy a magyar diplomások halandóságának átlagos vagy attól elmaradó fejlődése összefügghet a korábbi privilegizált helyzetükkel. Míg korábban kevesebben, jóval nagyobb szelekció mellett kerülhettek be az egyetemre, a rendszerváltozás után többek számára megnyílt a lehetőség arra, hogy a középiskolai tanulmányaik befejezése után vagy már felnőttként diplomát szerezhessenek. Ezen érvelés szerint a felsőoktatás expanziójával olyanok szerezhettek diplomát, akik életmódjukban erősebben kötődnek korábbi, alacsonyabb státusú csoportjukhoz, fékezve ezzel a diplomások élettartamának javulását. Ebben az esetben kevésbé könnyen magyarázható az érettségizettek átlagon felüli javulása. Valószínűbbnek látszik, hogy az érettségizettek számára is elérhető váltak olyan erőforrások, amelyek felhasználhatók voltak az ismert kockázatok elkerülésére vagy minimalizálására.

Az említett limitációk ellenére az adatok egyértelmüen azt sugallják igazolják, hogy az iskolai végzettség szerinti halandóságkülönbségek csökkentésének egyik lehetséges és egyértelmű módja az, ha egyre többek számára nyílnak meg az előrelépés lehetőségei az iskolázottság alsó tartományából a magasabb iskolázottsági szintek felé.

A felnőtt életkor egészére kiterjedő halandóságitábla-alapú elemzés, a különbségek abszolút mennyiségekben történő kifejezése megkönnyíti az eredmények értelmezését és lehetővé teszi néhány jól ismert összefüggés ellenőrzését. Az iskolázottság és a mortalitás Kitagawa és Hauser (1973) klasszikus írásában leírt életkor-sajátosságait, miszerint a különbségek a fiatal felnőttkor kezdeti szakaszán nagyobbak, az életkor előrehaladtával pedig mérséklődnek, már többen megerősítették (Shkolnikov et al., 1998; Klinger, 2001), és az újabb hazai adatok is ezzel megegyező eredményt mutatnak. A szélső csoportok kö- 
zött 70 éves korban várható élettartam a férfiaknál 4,9, a nőknél 2,8 évre csökkent a felnőtt életkor elején számolt 15,1 és 10,4 évről.

Korábbi tanulmányunkban részletesebben vizsgáltuk a társadalmi különbségek haláloki összetevőit. Eredményeink azt mutatták, hogy az alacsony társadalmi státusú csoportok felzárkózása nagyban függ a szív- és érrendszeri betegségek, a dohányzásnak tulajdonítható halálozások, és az ún. külső okok visszaszorításának a sikerétől (Bálint és Németh, 2018). E három csoport felel a diplomások és a nyolc osztály alatti végzettségűek közötti élettartam-különbség hozzávetőleg kétharmadáért (a férfiaknál 71,2\%-ért, a nőknél 65,8\%-ért).

A rendszerváltást követően gyors expanzió ment végbe a magyar felsőoktatásban. A főiskolai és egyetemi hallgatók száma a rendszerváltás körüli 100 ezer főről az ezredfordulóig a háromszorosára nőtt, a 2005/2006-os tanévben számuk elérte a 380 ezer főt, és az azt követő csökkenés ellenére a vizsgált időszak végén is 300 ezer fő felett maradt. ${ }^{3}$ A frissen végzettek száma ennél kevesebb volt. A kilencvenes évek elején évente 22-25 ezer fő lépett be a diplomások táborába, az ezredforduló után számuk megduplázódott, már több mint ötvenezer hallgató szerzett évente diplomát Magyarországon.

Nemzetközi tapasztalatok szerint az iskolázottság szerinti összetétel előnyös változása elősegíti a társadalom egészségi állapotának a javulását, hosszabb távon mérsékli a halálozást, és növeli a várható élettartamot (Lleras-Muney, 2005; Glied and Lleras-Muney, 2008; Mirowsky and Ross, 2003). Shkolnikov és szerzőtársai (2006), valamint Jasilionis és szerzőtársai (2007) skandináv, balti, valamint a közép- és kelet-európai egykori szocialista országok élettartamváltozásának az összetevőit határozták meg a 1980-as évek végétől az 1990-es évek végéig. A balti országokban a struktúra változása jelentős mértékben ellensúlyozta a férfiak halandóságának akkori romlását, míg a nőknél a nyereség a népesség összetételében bekövetkezett előnyös változásnak volt köszönhető. A finn és a cseh népesség élettartam-növekedését mindkét nemnél az alacsony képzettségűek halandóságának a csökkenése idézte elő (M-hatás), a populációs hatás a férfiaknál és a nőknél is elenyésző volt (0,1-0,5 év). Luy és szerzőtársai (2019) a struktúraváltozás jelentőségét Olaszország, Dánia és az Egyesült Államok felnőtt népességének 1990 és 2010 közötti időszakában vizsgálták. Mindhárom országban az élettartam-növekedés nagyobb részét a halálozás javulása okozta. Ugyanakkor a struktúra szerepe sem volt elhanyagolható, a hatás nagysága az amerikai férfiak élettartam-javulásának 15\%-ától, a dán nők hozzávetőleg

${ }^{3}$ http://www.ksh.hu/docs/hun/xstadat/xstadat_eves/i_zoi008.html 
40\%-áig terjedt. Hablicsek az 1986 és 1990, illetve a 2000 és 2004 közötti időszakot elemző tanulmányában arra a következtetésre jutott, hogy „....a népesség iskolai végzettségének emelkedése és a képzettebb népességcsoportok halandóságának erőteljesebb csökkenése egymást erősítette az elmúlt időszakban. Az összességében jelentős élettartam-emelkedés csak szerény mértékű maradt volna, ha csak a végzettségi szint emelkedik; ugyancsak szerény mértékű lett volna, ha csak a mortalitás javul." (Hablicsek, 2007: 44). Hablicsek megközelítése azonban nem volt képes a népesség- és a halandósági hatást egyidejüleg meghatározni. Jelen elemzés megmutatta, hogy mindkét nemnél a mortalitási hatás volt a jelentősebb (a férfiaknál 70,1\%, a nőknél 61,3\%), de a struktúra szerepe messze nem elhanyagolható.A vizsgált időszakban az éves élettartamnövekedés országos átlaga 6,5 évnyi fejlődéssel volt egyenértékű. A nőknél az élettartam-javulás kisebb volt (3,9 év), de a strukturális hatás abszolút nagysága nem tért el a férfiakétól (1,5 év), így pusztán a populációs hatás 8,5 év javulását biztosította. Láttuk, hogy az élettartam-javulás forrásai regionálisan eltérnek, a vidéki régiókban a mortalitási és a populációs hatás alig tért el a nőknél.

Mindezen eredmények azt is mutatják, hogy a halandóság szekuláris tendenciáinak jobb megértése érdekében figyelembe kell venni a népesség társadalmi összetételének dinamikáját. Továbbá hangsúlyoznunk kell az oktatáspolitika saját területén átnyúló, a népesség egészségi állapotára gyakorolt eminens szerepét. Fontos lenne, hogy a döntéshozók és az egészségügyben dolgozó szakemberek megértsék az oktatás e sajátos szerepének a jelentőségét, mint a társadalmi-gazdasági egyenlőtlenség csökkentésének, és mint az egészség tartós javításának potenciális eszközét.

Az országos adatok „fővárosi” és „vidéki” régiókra történő szétválasztását a Közép-Magyarországon előforduló jelentős adathiány tette szükségessé. A regionális elemzések tapasztalatai hozzájárulhatnak a mortalitás és a struktúra szerepének jobb megértéséhez. Nem ismert, hogy eltérő mortalitási és iskolázottsági szinteken a különböző tényezők milyen mértékben befolyásolják a fejlődést. Mivel a vidéki régiók iskolázottsági szintje alacsonyabb, mint Közép-Magyarországon, ezért a struktúra jelentősebb tartalékaival lehet számolni. 


\section{KÖSZÖNETNYILVÁNÍTÁS}

A halálozási adatokkal kapcsolatos problémáimmal Branyiczkiné Géczy Gabriellához fordulhattam, az oktatásstatisztikai adatokban Kovács Benedek nyújtott segítséget, a népesség-adatokat Kovács Marcell és Ináncsi Zita bocsátotta rendelkezésemre. Mindannyiuk segitségét köszönöm!

A tanulmány megjelenését a 2019. évi Felsőoktatási Intézményi Kiválósági Program II. 4. számú tématerület „A hazai vállalatok szerepének növelése a nemzet újraiparosításában” támogatta. 


\section{IRODALOM}

Acsádi Gy. (1963). A differenciális halandóság. In Dr. Szabady Egon (szerk.) Bevezetés a demográfiába (337-343. o.). Közgazdasági és Jogi Könyvkiadó, Budapest.

Andreev, E. M., Shkolnikov, V. M. and Begun, A. Z. (2002). Algorithm for decomposition of differences between aggregate demographic measures and its application to life expectancies, healthy life expectancies, parity-progression ratios and total fertility rates. Demographic Research, 7(14), 499-522.

Andreev, E. M. and Shkolnikov, V. M. (2012). An Excel spreadsheet for the decomposition of a difference between two values of an aggregate demographic measure by stepwise replacement running from young to old ages. MPIDR Technical Report TR-2012-002. Rostock, Max Planck Institute for Demographic Research.

Baker, D. P., Leon, J., Smith Greenaway., E. G., Collins, J. and Movit, M. (2011). The Education Effect on Population Health: A Reassessment. Population and Development Review, 37(2), 307-332.

Bálint L. (2016). Mennyire illeszkedik a magyar halandóság alakulása az epidemiológiai átmenet elméleteihez? Demográfia, 59(1), 5-57.

Bálint L. és Németh L. (2018). Az alkoholos halandóság szerepe a várható élettartam iskolai végzettség szerinti egyenlőtlenségeiben, Magyar Tudomány, 179(11), 1666-1679.

Balogh, S., Papp, R., Józan, P. and Császár, A. (2010). Continued improvement of cardiovascular mortality in Hungary - impact of increased cardio-metabolic prescriptions. BMC Public Health, 10(1), 422.

Banks, J., Marmot, M., Oldfield Z. and Smith, J.P. (2006). Disease and Disadvantage in the United States and in England, JAMA, 295(17), 2037-2045.

Belicza É. és Jánosi A. (2012). A heveny szívinfarktus előfordulásának és ellátásának vizsgálata a finanszírozási adatbázis elemzésével: 2004-2009. Orvosi Hetilap, 153, 102-112.

Black, D., Morris, J.N., Smith, C. and Townsend, P. (1982): Inequalities in Health: The Black Report. Middlesex, England: Penguin.

Blazek, J. and Dzúrová, D. (2000). The decline of Mortality in the Czech Republic during the Transition: A Counterfactual Case Study. In G. A Cornia and R. Panicciá (eds.) The Mortality Crisis in Transitional Economics (pp. 303-327). Oxford University Press.

Brønnum-Hansen, H. and Baadsgaard, M. (2007). Increasing social inequality in life expectancy in Denmark. European Journal of Public Health, 17(6), 585-586.

Brønnum-Hansen, H. and Baadsgaard, M. (2012). Widening social inequality in life expectancy in Denmark. A register-based study on social composition and mortality trends for the Danish population. BMC Public Health 2012, 12:994. http://www. biomedcentral.com/1471-2458/12/994

Camarda, C. G. (2012). MortalitySmooth: An R Package for Smoothing Poisson Counts with P-Splines. Journal of Statistical Software, 2012, 50(1), 1-24.

Clegg, L. X., Reichman, M. E., Miller, B. A., Hankey, B. F., Singh, G. K., Lin, Y. D., Goodman, M. T., Lynch, C. F., Schwartz, S. M., Chen, V. W., Bernstein, L., Gomez, S. L., Graff, J. J., Lin, C. C., Johnson, N. J. and Edwards, B. K. (2009). Impact of socioeconomic status on cancer incidence and stage at diagnosis: selected findings from the surveillance, epidemiology, and end results: National Longitudinal Mortality Study. Cancer Causes Control, 20(4), 417-35. 
Crimmins, E. M. and Saito, Y. (2001). Trends in Healthy Life Expectancy in the United States, 1970-1990: Gender, Racial, and Educational Differences. Social Science and Medicine, 52(11), 1629-1641.

Cutler, D. M. and Lleras-Muney, A. (2006). Education and Health: Evaluating Theories and Evidence. NBER Working Paper Series. Working paper 12352.

Daróczi E. (2004). Területi és társadalmi különbségek a középkorú férfiak és nők halandóságában Magyarországon 2001 körül. In Daróczi E. és Kovács K. (szerk.): Halálozási viszonyok az ezredfordulón: Társadalmi és földrajzi választóvonalak (103-136. 0.). KSH NKI, Kutatási Jelentés 77.

Davey-Smith G., Hart, C., Hole, D., McKinnon, P., Gillis, C., Watt, G., Blane, D. and Hawthorne, V. (1998). Education and occupational class: which is the more important indicator of mortality risk. Journal of Epidemiology and Community Health, 52(3), 153-160.

Deboosere, P., Gadayne, S. and van Oyen H. (2009). The 1991-2004 Evolution in Life Expectancy by Educational Level in Belgium based on Linked Census and Population Register Data. European Journal of Population, 25(2), 175-196.

Dobbins, M. and Kwiek, M. (2017). Europeanisation and globalisation in higher education in Central and Eastern Europe: 25 years of changes revisited (1990-2015). European Educational Research Journal, 16(5), 519-528.

Dolbhammer, G., Rau, R. and Kytir, J. (2005). Trends in educational and occupational differentials in all-cause mortality in Austria between 1981/82 and 1991/92. Wiener Klinische Wochenschrift, 117(13/14), 468-479.

Elo, I. T. (2009). Social Class Differentials in Health and Mortality: Patterns and Explanations in Comparative Perspective. Annual Review of Sociology, 35, 553-572.

Elo, I. T. and Preston, S. H. (1996). Educational differentials in mortality: United States. Social Science and Medicine, 42(1), 47-57.

Elo, I. T., Martikainen, P. and Smith, K. P. (2006). Socioeconomic differentials in mortality in Finland and the United States: the role of education. European Journal of Population, 22(2), 179-203.

European Union 2013: Health inequalities in the EU - Final report of a consortium. Consortium lead: Sir Michael Marmot. European Commission Directorate-General for Health and Consumers. https:/ec.europa.eu/health//sites/health/files/social_ determinants/docs/healthinequalitiesineu_2013_en.pdf [letöltve: 2020. 05. 18.]

Feinstein, L., Sabates, R., Anderson, Tashweka, M., Sorhaindo, A. and Hammond, C. (2006). What are the effects of education on health. In R. Desjardin and T. Schuller (eds.) Measuring the Effects of Education on Health and Civic Engagement Proceedings of the Copenhagen Symposium (pp. 171-354). OECD.

Fihel, A., Fihel, A. and Pechholdová, M. (2017). Between 'Pioneers' of the Cardiovascular Revolutionand Its 'Late Followers': Mortality Changes in the Czech Republic and Poland Since 1968. European Journal of Population, 33(5), 651-678.

Gavurova, B. and Vagasova, T. (2018). Potential gains in life ecpectancy by eliminating deaths from cardiovascular diseases and diabetes mellitus in the working life ages among Slovak population. Health Economics Review, 8(1), 16.

Gero, K., Eshak, E. E., Ma, E., Takahashi, H., Noda, H. and Hiroyasu, H. (2015). Health Disparities in Ischaemic Heart Disease Mortality in Hungary From 1970 to 2010: An Age-Period-Cohort Analysis. Journal of Epidemiology, 25(6), 399-406. 
Geyer, S., Hemstrom, O., Peter, R. and Vagero, D. (2006). Education, income, and occupational class cannot be used interchangeably in social epidemiology. Empirical evidence against a common practice. Journal of Epidemiology and Community Health, 60(9), 804-810.

Glied, S. and Lleras-Muney, A. (2008). Technological Innovation and Inequality in Health. Demography, 45(3), 741-61.

Grigoriev, P., Scholz, R. and Shkolnikov, V. M. (2019). Socioeconomic differences in mortality among 27 million economically active Germans: a cross-sectional analysis of the German Pension Fund data. BMJ Open;9:e028001.

Hablicsek L. (2007). Halandósági egyenlőtlenségek: a várható élettartam és az elhalálozási valószínúségek alakulása. In Hablicsek László - Kovács Katalin In Hablicsek L. és Kovács K. (2007): Az életkilátások differenciálódása iskolázottság szerint, 1986-2005 (13-48. o.). Központi Statisztikai Hivatal Népességtudományi Kutatóintézetének Kutatási jelentései 84.

Henriksson, G., Allebeck, P., Weitoft, R. G. and Thelle, D. (2006). Income distribution and mortality: implications from a comparison of individual level analysis and multilevel analysis of Swedish data. Scandinavian Journal of Public Health, 34(2), 287-294.

Híves T. és Kozma T. (2014). Az expanzió vége? Educatio, 2, 239-252.

Hoffmann, R. (2008). Socioeconomic Differences in Old Age Mortality. Springer, Dordrecht.

Howard, V. J., Cushman, M., Pulley, L., Gomez, C. R., Go, R. C. and Prineas, R. J. G. (2005). The reasons for geographic and racial differences in stroke study: Objectives and design. Neuroepidemiology, 25, 135-143.

Hummer, R. A. and Hernandez, E. M. (2013). The effect of educational Attainment on adult mortality in the United States. Population Bulletin, 68(1), 1-16.

Hummer, R. A. and Lariscy, J. T. (2011). Educational Attainment and Adult Mortality. In R. G. Rogers and E. M. Crimmins (Eds): International Handbook of Adult Mortality (pp. 241-262). Springer, New York.

James, C., Devaux, M. and Sassi, F. (2017). Inclusive growth and health. OECD Health Working Paper No 103.

Jasilionis, D., Jdanov, D. and Leinsalu, M. (2007). Der Zusammenhang von Bildung und Lebenserwartung in Mittel-und Osteuropa. Education and Mortality in Central and Eastern Europe. Jahrbuch der Max-Planck-Gesellschaft, 2006-2007, 103-108.

Jdanov, D. A., Shkolnikov, V. M., van Raalte, A. A. and Andreev, Evgeny M. A. and Andreev E. M. A. (2017). Decomposing Current Mortality Differences Into Initial Differences and Differences in Trends: The Contour Decomposition Method. Demography, 54(4), 1579-1602.

Józan, P. (2004). Csökkenő szív- és érrendszeri halandóság, javuló életkilátások Magyarországon. Magyar Epidemiológia, 1, 31-48.

Józan, P. (2012). Rendszerváltozás és epidemiológiai korszakváltás Magyarországon. Orvosi Hetilap, 153(17), 662-677.

Jung-Choi, K., Khang, Y. H., Cho, H. J. and Yun, S. C. (2014). Decomposition of educational differences in life expectancy by age and causes of death among South Korean adults. BMC Public Health, 14:560; http://www.biomedcentral.com/1471-2458/14/560

Kalediene, R. and Petrauskiene, J. (2000). Inequalities in life expectancy in Lithuania by level of education. Scandinavian Journal of Public Health, 28(1), 4-9. 
Kalediene, R. and Petrauskiene, J. (2005). Inequalities in mortality by education and socioeconomic transition in Lithuania: equal opportunities? Public Health, 119, 808-815.

Kapitány B. és Spéder Zs. (2004). Szegénység és depriváció: társadalomszerkezeti összefüggések nyomában. KSH NKI Mühelytanulmányok 4. kötet.

Kézdi G. (2004). Iskolázottság és kerestek. In Fazekas K. és Varga J. (szerk.): Munkaeröpiaci Tükör, MTA Közgazdaságtudományi Intézet Országos Foglalkoztatási Közalapítvány, Budapest.

Klinger A. (1963). A rákhalandóság társadalmi-foglalkozási különbségei Magyarországon. Demográfia, 6(3), 419-426.

Kitagawa, E. M., and Hauser, P.M. (1973). Differential Mortality in the United States: A Study in Socioeconomic Epidemiology. Cambridge: Harvard University Press.

Klinger A. (1986). Socio-economical Mortality Differentials in Hungary. International Seminar on the Socio-Economic Aspects of Differential Mortality. Socio-economic Differential Mortality 5 (pp. 17-63). Hungarian Central Statistical Office.

Klinger A. (1987). A halandóság társadalmi foglalkozási különbségei Magyarországon. Demográfia, 30(2-3), 240-272.

Klinger A. (2001). Halandósági különbségek Magyarországon iskolai végzettség szerint. Demográfia, 44(3-4), 227-258.

Klinger, A. (2007). A halandóság társadalmi különbségei Magyarországon a XXI. század elején. Demográfia, 50(2-3), 252-281.

Kolosi T. és Keller T. (2012). Megéri tanulni...? Származás, iskola, foglalkozás, kereset - utak és elágazások a rendszerváltást követően. In Kolosi T. és Tóth I. Gy. (szerk.): Társadalmi Riport (41-64. o.). Budapest: TÁRKI.

Koskinen, S. and Martelin, T. (1994). Why are socioeconomic mortality differences smaller among women than among men? Social Science and Medicine, 38(10), 1385-1396.

Kovács, K. (2007). Halandósági különbségek a 30-64 éves népesség körében. In Hablicsek L. - Kovács K. (Szerk.): Az életkilátások differenciálódása iskolázottság szerint, 19862005 (pp. 49-106). Központi Statisztikai Hivatal Népességtudományi Kutatóintézetének Kutatási Jelentései 84. Budapest.

Kovács K. and Bálint L. (2014). Education, Income, Material Deprivation and Mortality. Demográfia, English Edition, 57(5), 73-89.

Krumins, J. and Usackis, U. (2000). The Mortality Consequences of the Transition to Market Economy in Latvia 1991-1995. In G. A. Cornia and R. Panicciá (eds.): The Mortality Crisis in Transitional Economics (pp. 280-302). Oxford University Press.

KSH (1995). Területi Halandósági Táblák. Budapest: Központi Statisztikai Hivatal.

KSH (2012). A halandóság földrajzi különbségei Magyarországon, 2011. Budapest: Központi Statisztikai Hivatal.

Kunst, A. E. (1997). Cross-national comparisons of socio-economic differences in mortality. Thesis Erasmus University, Rotterdam.

Kunst A. E. and Mackenbach, J. P. (1994). The size of mortality differences associated with educational level in nine industrialized countries. American Journal of Public Health, 84(6), 932-937.

Kunst, A. E., Groenhof, F. and Mackenbach, J. P. (2000). EU Working Group on Socioeconomic Inequalities in Health. Inégalités Sociales de Mortalité Prématurée: La France Comparée aux Autres Pays Européens (pp. 53-68). 
Lahelma, E. and Valkonen, T. (1990). Health and Social Inequities in Finland and elsewhere. Social Science and Medicine, 31(3), 257-265.

Link, B. G. and Phelan, J. (1995). Social Conditions As Fundamental Causes of Disease. Journal of Health and Social Behavior, Extra Issue: Forty Years of MedicalSociology: The State of the Art and Directions for the Future, 35, 80-94.

Lleras-Muney, A. (2005). The relationship between education and adult mortality in the United States. The Review of Economics Studies, 72(1), 189-221.

Loichinger, E. and Weber, D. (2016). Trends in Working Life Expectancy in Europe. International Institute for Applied Systems Analysis, Working Paper WP-16-004, Laxenburg, Austria.

Luy, M., Zannella, M., Wegner-Siegmundt, C., Minagawa, Y., Lutz, W. and Caselli, G., (2019). The impact of increasing education levels on rising life expectancy: a decomposition analysis for Italy, Denmark, and the USA. Genus, 75(1), 11.

Mackenbach, J. P. (2006). Health Inequalities: Europe in Profile. Report commissioned by the UK Presidency of the EU), Erasmus Medical Centre, Rotterdam, 2006.

Mackenbach, J. P. (2018). Health Inequalities Persistence and change in European welfare states. Oxford University Press.

Mackenbach, J. P., Kunst, A. E., Groenhof, F., Borgan, J-K., Costa, G., Faggiano, F., Józan, P., Leinsalu, M., Martikainen, P. and Rychtarikova, J. (1999). Socioeconomic inequalities in mortality among women and among men: an international study. American Journal of Public Health, 89(12), 1800-1806.

Mackenbach, J. P., Bos, V., Andersen, O., Cardano, M., Costa, G., Harding, S., Reid, A., Hemström, Ö., Valkonen, T. and Kunst A. E. (2003). Widening socioeconomic inequalities in mortality in six Western European countries. International Journal of Epidemiology, 32(5), 830-837.

Mackenbach, J. P., Stirbu, I., Roskam, A-J. R., Schaap, M. M., Menvielle, G., Leinsalu, M. and Kunst, A. E. (2008). For the European Union Working Group on Socioeconomic Inequalities in Health Socioeconomic Inequalities in Health in 22 European Countries. The New England Journal of Medicine, 358(23), 2468-2481.

Mackenbach, J. P., Kulhánová, I., Bopp, M., Borrell, C., Deboosere, P., Kovács, K., Looman, C. W. N., Leinsalu, M., Mäkelä, P., Martikainen, P., Menvielle, G., Rodríguez-Sanz, M., Rychtař́ḱková, J. and de Gelder, R. (2015). Inequalities in Alcohol-Related Mortality in 17 European Countries: A Retrospective Analysis of Mortality Registers. PLOS Medicine, 12(12), e1001909. DOI:10.1371/journal.pmed.1001909.

Mackenbach, J. P., Valverde, J. R., Artnik, B., Bopp, M., Brønnum-Hansen, H., Debooseree, P., Kalediene, R., Kovács, K., Leinsalu, M., Martikainen, P., Menvielle, G., Regidor, E., Rychtaríková, J., Rodriguez-Sanz, M., Vineis, P., White, C., Wojtyniak, B., Hu, Y. and Nusselder, W. J. (2018). Trends in health inequalities in 27 European countries. Proceedings of the National Academy of Sciences, 115(25), 6440-6445.

Leinsalu, M., Vågerö, D. and Kunst A. E. (2003). Estonia 1989-2000: enormous increase in mortality differences by education. International Journal of Epidemiology, 32(6), 1081-1087.

Marmot, M. G., Shipley, M. J. and Rose, G. (1984). Inequalities in Death-Specific Explanations or a General Pattern? Lancet, 323(8384), 1003-1006. 
McDonough, P. G., Duncan, G. J., Williams, D. and House, J. (1997). Income dynamics and adult mortality in the United States, 1972 through 1989. American Journal of Public Health, 87(9), 1476-1483.

Meara, E. R., Richards, S. and Cutler, D. M. (2008). The Gap Gets Bigger: Changes In Mortality And Life Expectancy, By Education, 1981-2000. Health Affairs, 27(2), 350-360.

Miech, R., Pampel, F., Kim, J. and Rogers, R. G. (2011). The Enduring Association between Education and Mortality: The Role of Widening and Narrowing Disparities. American Sociological Review, 76(6), 913-934.

Mirowsky, J. and C.E. Ross. (2003). Education, Social Status, and Health. New York, NY, Aldine de Gruyter.

Mirowsky, John - Ross, Catherina E. Mirowsky, J. and Ross, C. E. (1998). Education, Personal Control, Lifestyle and Health. A Human Capital Hypothesis. Research on Aging. 20(4), 415-449.

Murphy, M., Bobak, M., Nicholson, A., Rose, R. and Marmot, M. (2006). The widening gap in mortality by educational level in the Russian Federation, 1980-2001. American Journal of Public Health, 96(7), 1293-1299.

Murtin, F., Mackenbach, J., Domantas, J. and D'Ercole, M. M. (2017). Inequalities in longevity by education in OECD countries: Insights from new OECD estimates, OECD Statistics Working Papers 2017/02.

Nagy Gy. (2000). Munkanélküliség a kilencvenes években. In Kolosi T., Tóth I. Gy. és Vukovich Gy. (szerk.): Társadalmi riport 2000 (79-98. o.). Budapest: TÁRKI.

Olshansky S. J., Antonucci, T., Berkman, L., Binstock, R. H., Boersch-Supan, A., Cacioppo, J. T., Carnes, B. A., Carstensen, Laura L., Fried, L. P., Goldman, D. P., Jackson, J., Kohli, M., Rother, J., Zheng, Y. and Rowe, Y. (2012). Differences in life expectancy due to race and educational differences are widening, and many may not catch up. Health Affairs, (Millwood), 31(8), 1803-13.

Östergren, O. (2017). Understanding the Educational Gradient in Mortality. Academic dissertation for the Degree of Doctor of Philosophy in Sociology at Stockholm. Department of Sociology, Stockholm University.

Pappas, G., Queen, S., Hadden, W. and Fisher, G. (1993). Increasing disparity in mortality between socioeconomic groups in the United States, 1960 and 1986. New England Yournal of Medicine, 329(2), 103-109.

Phelan, J. C., Link, B. G., Diez-Roux, A., Kawachi, I. and Levin, B. (2004). Fundamental Causes of Social Inequalities in Mortality: A Test of the Theory. Journal of Health and Social Behavior, 45(3), 265-285

Prescott, E. and Vestbo, J. (1999). Socioeconomic status and chronic obstructive pulmonary disease. Thorax, 54, 737-741.

Preston, S. H.-Elo, I. T. Preston, S. H. and Elo, I. T. (1995). Are Educational Differentials in Adult Mortality Increasing in the United States? Journal of Aging and Health, 7(4), 476-496.

Rogers, R. G., Hummer, R. A. and Nam, C. B. (2000). Living and Dying in the USA: Behavioral, Health, and Social Differentials of Adult Mortality. New York: Academic Press.

Ross, C. E. and Wu, C-L. (1995). The Links Between Education and Health. American Sociological Review, 60(5), 719-745. 
Ross, C. E. and Mirowsky, J. (1998). Refining the association between education and health: the effects of quantity, credential, and selectivity. Demography, 36(4), 445-460.

Ross, C. E. and Mirowsky, J. (2003). Education, Social Status, and Health. Aldine de Gruyter, New York.

Rostron, B. L., Boies, J. L. and Arias, E. (2010). Education Reporting and Classification on Death Certificates in the United States. Vital and Health Statistics, Series 2, Number 151.

Rychtariková, J. (2004). The case of the Czech Republic. Determinants of the recent favourable turnover in mortality. Demographic Research. Special Collection, 2, 105-138.

Rychtaříková, J. and Hulíková-Tesárková, K. (2015). Potential Reduction in Mortality Associated with the Shifts of Population Educational Structures in the Czech Republic. In J. Dorszewska and W. Kozubski (eds.) Senescence - Physiology or Pathology (pp. 139-156). IntechOpen, DOI: 10.5772/intechopen.69635.

Sasson, I. (2016). Diverging Trends in Cause-Specific Mortality and Life Years Lost by Educational Attainment: Evidence from United States Vital Statistics Data, 1990-2010. PLOS ONE, 11(10), e0163412. doi:10.1371/journal.pone.0163412

Sasson, I. and Hayward, M. D. (2019). Association Between Educational Attainment and Causes of Death Among White and Black US Adults, 2010-2017. JAMA, 322(8), 756-763.

Schultz, W. M., Kelli, H. M., Lisko, J. C., Varghese, T., Shen, J., Sandesara, P., Quyyumi, A. A., Taylor, H. A., Gulati, M., Harold, J. G., Mieres, J. H., Ferdinand, K. C., Mensah, G. A. and Sperling, L. S. (2018). Socioeconomic Status and Cardiovascular Outcomes. Circulation, 137(20), 2166-2178.

Shkolnikov, V. M., Leon, D. M., Adamets, S., Andreev, E. and Deev, A. (1998). Educational level and adult mortality in Russia: an analysis of routine data 1979 to 1994. Social Science and Medicine, 47(3), 357-369.

Shkolnikov, V. M., Andreev, E. M., Jasilionis, D., Leinsalu, M., Antonova, O. I. and McKee, M. (2006). The changing relation between education and life expectancy in central and eastern Europe in the 1990s. Journal of Epidemiology and Community Health, 60, 875-881.

Sihvonen, A-P., Kunst, A. E., Lahelma, E., Valkonen, T. and Mackenbach, J. P. (1998). Occupational class, education and income are distinct but related components measuring multiple aspects of a person's socioeconomic status. Social Science and Medicine, 47(3), 303-315.

Sorlie, P. D., Backlund, E. and Keller. J. B. (1995). U.S. Mortality by Economic, Demographic, and Social Characteristics: The National Longitudinal Mortality Study. American Journal of Public Health, 85(7), 949-56.

Sorlie, P. D and Johnson, N. J. (1996). Validity of education information on the death certificate. Epidemiology, 7(4), 437-439.

Steenland, K., Hu, S. and Walker, J. (2004). All-Cause and Cause-Specific Mortality by Socioeconomic Status Among Employed Persons in 27 US States 1984-1997. American Journal of Public Health, 94(6), 1037-1042. 
Stringhini, S., Rousson, V., Viswanathan, B., Gedeon, J., Paccaud, F. and Bovet, P. (2014). Association of Socioeconomic Status with Overall and Cause Specific Mortality in the Republic of Seychelles: Results from a Cohort Study in the African Region. Plos One. https://doi.org/10.1371/journal.pone.0102858

Szabady E. (1963). A magyar halandóság társadalmi gazdasági tényezőinek legújabb alakulása. Demográfia, 6(4), 441-448.

Unger, R. and Schulze, A. (2013). Can We Really (All) Work Longer? Trends in Healthy Life Expectancy According to Social Stratum in Germany. Comparative Population Studies - Zeitschrift für Bevölkerungswissenschaft, 38(3), 565-582.

Valkonen, T. (2006). Social Inequalities in Mortality. In Caselli, G., Vallin, J. and Wunsch, G. (eds.). Demography: analysis and synthesis (pp. 195-206). Volume II, Amsterdam: Elsevier Scientific Publ. Co.

Vallin, J. (2013). Inequalities in Life Expectancy Between and Within European Countries. In G. Neyer, G. Anderson, H. Kulu, L. Bernardi and C. Bühler (eds.), The Demography of Europe (pp. 139-173). Springer.

Vandenheede, H., Vikhireva, O., Pikhart, H., Kubinova, R., Malyutina, S., Pajak, A., Tamosiunas, A., Peasey, A., Simonova, G., Topor-Madry, R., Marmot, M. and Bobak, M., (2014). Socioeconomic inequalities in all-cause mortality in the Czech Republic, Russia, Poland and Lithuania in the 2000s: findings from the HAPIEE Study. Journal of Epidemiology and Community Health, 68(4), 297-303.

Vastag Z. (2015). Rétegződés és iskolázottság. In Huszár Ákos (szerk.): 2011. évi népszámlálás 15. A társadalom rétegződése (55-69. o.). Budapest: Központi Statisztikai Hivatal.

Willekens, F. (2016). Demographic Transitions in Europe and the World. In K. Matthijs, K. Neels, C. Timmerman, J. Haers and S. Mels (eds.), Population Change in Europe, the Middle-East and North Africa. Beyond the Demographic Divide (pp. 13-44). Routledge.

Winkleby, M. A. and Cubbin C. (2003). Influence of individual and neighborhood socioeconomic status on mortality among black, Mexican-American, and white women and men in the United States. Journal of Epidemiology and Community Health, 57(6), 444-452.

Yang, K., Zhang, Y., Saito, E., Rahman, S., Gupta, P. C., Sawada, N., Tamakoshi, A., Gao, Y-T., Koh, W-P., Shu, X-O., Tsuji, I., Sadakane, A., Nagata, C., You, S-L., Yuan, J-M., Shin, M-H., Chen, Y., Pan, W-H., Pednekar, M. S., Tsugane, S., Cai, H., Xiang, Y., Ozasa, K., Tomata, Y., Kanemura, S.,Sugawara, Y., Wada, K., Wang, R., Ahn, Y-O., Yoo, K-Y., Ahsan, H.,Chia, K. S., Boffetta, P., Kang, D., Potter, J. D., Inoue, M., Zheng, W-N. (2019). Association between educational level and total and cause-specific mortality: a pooled analysis of over 694000 individuals in theAsia Cohort Consortium. BMJ Open, 2019;9:e026225. doi:10.1136/bmjopen-2018-026225

Zhou, S., Zou, G., Chen, X., Yu, H., Wang, J., Fang, P. and Song, F. (2019). Educational attainment and mortality: results from the Sixth Population Census in China. Journal of Global Health, 9(2), 1-11. 


\section{MELLÉKLET}

M1. táblázat: $A 25$ éves és annál idősebb férfiak iskolai végzettség szerinti száma és aránya 1990-ben és 2011-ben, valamint változása NUTS2-régiók szerint

\begin{tabular}{|c|c|c|c|c|c|}
\hline Régiók & $\begin{array}{l}\text { Kevesebb, } \\
\text { mint } 8 \text { osztály }\end{array}$ & $\begin{array}{c}\text { Legfeljebb } \\
\text { szakmunkás }\end{array}$ & Érettségizett & Diplomás & Együtt \\
\hline \multicolumn{6}{|c|}{1990} \\
\hline Közép-Magyarország & $126165(13,9)$ & $430115(47,5)$ & $181666(20,1)$ & $168073(18,6)$ & $906019(100,0)$ \\
\hline Közép-Dunántúl & $66196(19,5)$ & $185245(54,7)$ & $54221(16,0)$ & $33138(9,8)$ & $338800(100,0)$ \\
\hline Nyugat-Dunántúl & $61938(19,9)$ & $165629(53,1)$ & $53202(17,1)$ & $30977(9,9)$ & $311746(100,0)$ \\
\hline Dél-Dunántúl & $68295(21,9)$ & $168606(54,0)$ & $46632(14,9)$ & $28979(9,3)$ & $312512(100,0)$ \\
\hline Észak-Magyarország & $85821(21,5)$ & $212789(53,3)$ & $65003(16,3)$ & $35578(8,9)$ & $399191(100,0)$ \\
\hline Észak-Alföld & $116917(25,7)$ & $240289(52,9)$ & $59743(13,2)$ & $37142(8,2)$ & $454091(100,0)$ \\
\hline Dél-Alföld & $106665(24,7)$ & $228827(53,0)$ & $59547(13,8)$ & $36814(8,5)$ & $431853(100,0)$ \\
\hline Együtt & $631997(20,0)$ & $1631500(51,7)$ & $520014(16,5)$ & $370701(11,8)$ & $3154212(100,0)$ \\
\hline \multicolumn{6}{|c|}{2011} \\
\hline Közép-Magyarország & $14874(1,5)$ & $394254(39,8)$ & $301486(30,4)$ & $281189(28,4)$ & $991803(100,0)$ \\
\hline Közép-Dunántúl & $9926(2,6)$ & $213547(56,9)$ & $96076(25,6)$ & $55941(14,9)$ & $375490(100,0)$ \\
\hline Nyugat-Dunántúl & $8095(2,3)$ & $192618(55,7)$ & $92599(26,8)$ & $52644(15,2)$ & $345956(100,0)$ \\
\hline Dél-Dunántúl & $11290(3,6)$ & $185653(58,7)$ & $75166(23,8)$ & $44224(14,0)$ & $316333(100,0)$ \\
\hline Észak-Magyarország & $16586(4,2)$ & $226469(57,4)$ & $100479(25,5)$ & $51113(13,0)$ & $394647(100,0)$ \\
\hline Észak-Alföld & $24982(5,1)$ & $291841(59,6)$ & $109266(22,3)$ & $63243(12,9)$ & $489332(100,0)$ \\
\hline Dél-Alföld & $17431(4,0)$ & $258132(58,6)$ & $104272(23,7)$ & $60724(13,8)$ & $440559(100,0)$ \\
\hline Együtt & $103184(3,1)$ & $1762514(52,5)$ & $879344(26,2)$ & $609078(18,2)$ & $3354120(100,0)$ \\
\hline \multicolumn{6}{|c|}{ Változás főben és százalékban } \\
\hline Közép-Magyarország & $-111291(-88,2)$ & $-35861(-8,3)$ & $119820(66,0)$ & $113116(67,3)$ & $85784(9,5)$ \\
\hline Közép-Dunántúl & $-56270(-85,0)$ & $28302(15,3)$ & $41855(77,2)$ & $22803(68,8)$ & $36690(10,8)$ \\
\hline Nyugat-Dunántúl & $-53843(-86,9)$ & $26989(16,3)$ & $39397(74,1)$ & $21667(69,9)$ & $34210(11,0)$ \\
\hline Dél-Dunántúl & $-57005(-83,5)$ & $17047(10,1)$ & $28534(61,2)$ & $15245(52,6)$ & $3821(1,2)$ \\
\hline Észak-Magyarország & $-69235(-80,7)$ & $13680(6,4)$ & $35476(54,6)$ & $15535(43,7)$ & $-4544(-1,1)$ \\
\hline Észak-Alföld & $-91935(-78,6)$ & $51552(21,5)$ & $49523(82,9)$ & $26101(70,3)$ & $35241(7,8)$ \\
\hline Dél-Alföld & $-89234(-83,7)$ & $29305(12,8)$ & $44725(75,1)$ & $23910(64,9)$ & $8706(2,0)$ \\
\hline Együtt & $-528813(-83,7)$ & $131014(8,0)$ & $359330(69,1)$ & $238377(64,3)$ & $199908(6,3)$ \\
\hline
\end{tabular}


M2. táblázat: A 25 éves és annál idősebb női népesség iskolai végzettség szerinti száma és aránya 1990-ben és 2011-ben, valamint a változása NUTS2-régiók szerint

\begin{tabular}{|c|c|c|c|c|c|}
\hline Régiók & $\begin{array}{l}\text { Kevesebb, } \\
\text { mint } 8 \text { osztály }\end{array}$ & $\begin{array}{c}\text { Legfeljebb } \\
\text { szakmunkás }\end{array}$ & Érettségizett & Diplomás & Együtt \\
\hline \multicolumn{6}{|c|}{1990} \\
\hline Közép-Magyarország & $247524(22,7)$ & $440556(40,3)$ & $263455(24,1)$ & $140654(12,9)$ & $1092189(100,0)$ \\
\hline Közép-Dunántúl & $108726(29,4)$ & $167110(45,1)$ & $67907(18,3)$ & $26433(7,1)$ & $370176(100,0)$ \\
\hline Nyugat-Dunántúl & $105065(30,0)$ & $153634(43,8)$ & $66710(19,0)$ & $25249(7,2)$ & $350658(100,0)$ \\
\hline Dél-Dunántúl & $121210(33,8)$ & $155648(43,4)$ & $57459(16,0)$ & $24396(6,8)$ & $358713(100,0)$ \\
\hline Észak-Magyarország & $160091(34,6)$ & $190687(41,2)$ & $81475(17,6)$ & $30228(6,5)$ & $462481(100,0)$ \\
\hline Észak-Alföld & $192283(37,2)$ & $205920(39,9)$ & $81905(15,9)$ & $36275(7,0)$ & $516383(100,0)$ \\
\hline Dél-Alföld & $171090(34,6)$ & $208636(42,2)$ & $80543(16,3)$ & $33684(6,8)$ & $493953(100,0)$ \\
\hline Együtt & $\begin{array}{r}1105989 \\
(30,3)\end{array}$ & $1522191(41,8)$ & $699454(19,2)$ & $316919(8,7)$ & $3644553(100,0)$ \\
\hline \multicolumn{6}{|c|}{2011} \\
\hline Közép-Magyarország & $48278(4,0)$ & $380004(31,7)$ & $427779(35,7)$ & $340886(28,5)$ & $1196947(100,0)$ \\
\hline Közép-Dunántúl & $27412(6,5)$ & $198452(47,0)$ & $127942(30,3)$ & $68313(16,2)$ & $422119(100,0)$ \\
\hline Nyugat-Dunántúl & $22643(5,8)$ & $181158(46,3)$ & $121578(31,1)$ & $65600(16,8)$ & $390979(100,0)$ \\
\hline Dél-Dunántúl & $31543(8,5)$ & $180042(48,5)$ & $101225(27,3)$ & $58304(15,7)$ & $371114(100,0)$ \\
\hline Észak-Magyarország & $46387(10,0)$ & $215956(46,4)$ & $135291(29,1)$ & $67688(14,5)$ & $465322(100,0)$ \\
\hline Észak-Alföld & $61026(10,8)$ & $261677(46,4)$ & $151436(26,9)$ & $89766(15,9)$ & $563905(100,0)$ \\
\hline Dél-Alföld & $43594(8,5)$ & $242985(47,3)$ & $144352(28,1)$ & $82763(16,1)$ & $513694(100,0)$ \\
\hline Együtt & $280883(7,2)$ & $1660274(42,3)$ & $1209603(30,8)$ & $773320(19,7)$ & $3924080(100,0)$ \\
\hline \multicolumn{6}{|c|}{ Változás főben és százalékban } \\
\hline Közép-Magyarország & $-199246(-80,5)$ & $-60552(-13,7)$ & $164324(62,4)$ & $200232(142,4)$ & $104758(9,6)$ \\
\hline Közép-Dunántúl & $-81314(-74,8)$ & $31342(18,8)$ & $60035(88,4)$ & $41880(158,4)$ & $51943(14,0)$ \\
\hline Nyugat-Dunántúl & $-82422(-78,4)$ & $27524(17,9)$ & $54868(82,2)$ & $40351(159,8)$ & $40321(11,5)$ \\
\hline Dél-Dunántúl & $-89667(-74,0)$ & $24394(15,7)$ & $43766(76,2)$ & $33908(139,0)$ & $12401(3,5)$ \\
\hline Észak-Magyarország & $-113704(-71,0)$ & $25269(13,3)$ & $53816(66,1)$ & $37460(123,9)$ & $2841(0,6)$ \\
\hline Észak-Alföld & $-131257(-68,3)$ & $55757(27,1)$ & $69531(84,9)$ & $53491(147,5)$ & $47522(9,2)$ \\
\hline Dél-Alföld & $-127496(-74,5)$ & $34349(16,5)$ & $63809(79,2)$ & $49079(145,7)$ & $19741(4,0)$ \\
\hline Együtt & $-825106(-74,6)$ & $138083(9,1)$ & $510149(72,9)$ & $456401(144,0)$ & $279527(7,7)$ \\
\hline
\end{tabular}




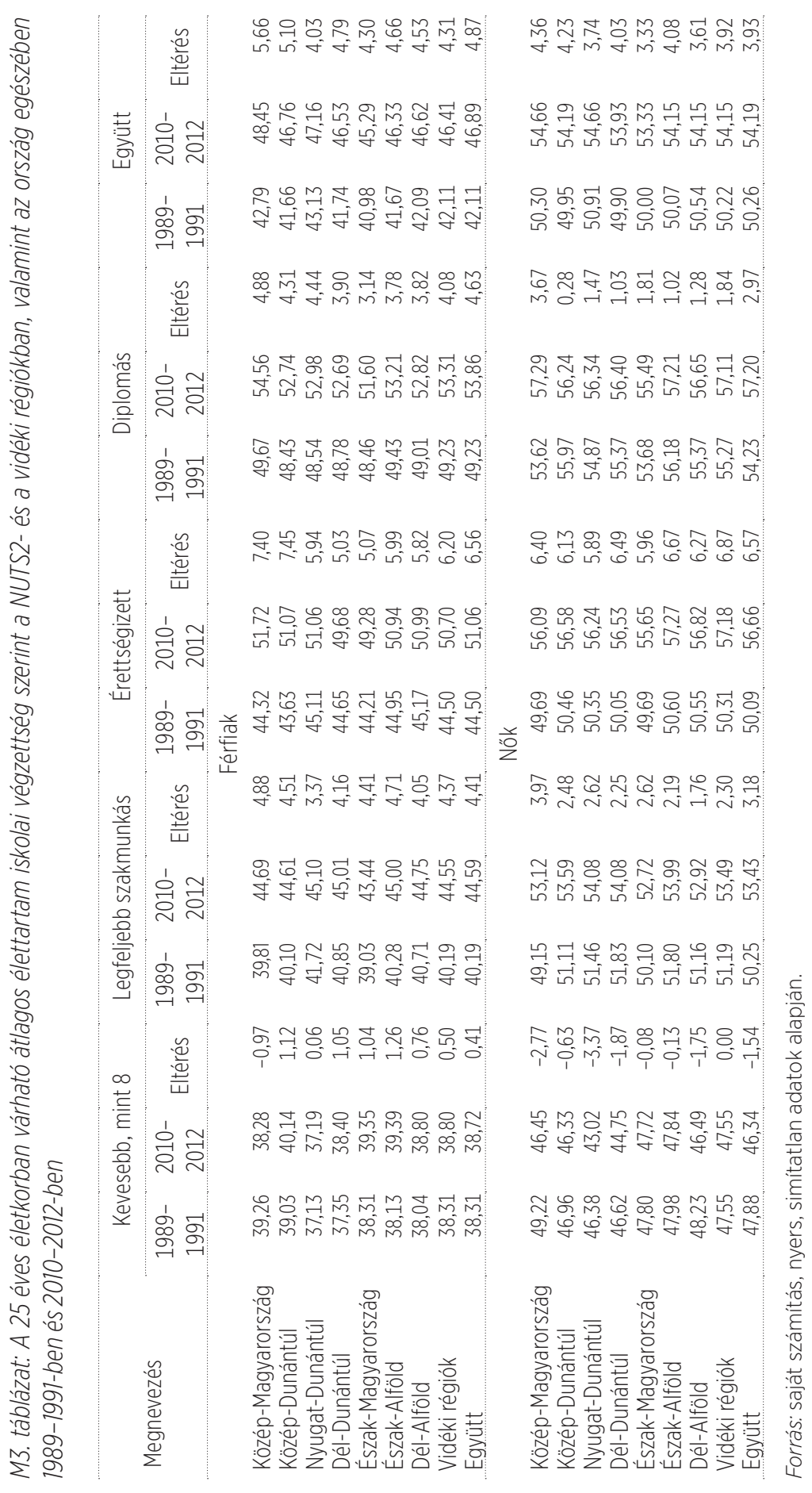


M4. táblázat: A különböző iskolázottsági csoportok halandóságváltozásának és az iskolázottsági struktúra változásának hozzájárulásai a népesség várható élettartamának a változásához

(év)

\begin{tabular}{|c|c|c|c|c|c|c|}
\hline \multirow[b]{2}{*}{ Régiók } & \multicolumn{4}{|c|}{ Mortalitási hatás } & \multirow{2}{*}{\multicolumn{2}{|c|}{$\begin{array}{cc} & \text { Teljes } \\
\text { változás } \\
\text { Populációs } & 1989-1991 \\
\text { hatás } & \text { és } \\
& 2010-2012 \\
& \text { között }\end{array}$}} \\
\hline & $\begin{array}{l}\text { kevesebb, } \\
\text { mint } 8 \\
\text { osztály }\end{array}$ & $\begin{array}{l}\text { legfeljebb } \\
\text { szakmun- } \\
\text { kás }\end{array}$ & Érettségi & Diploma & & \\
\hline \multicolumn{7}{|c|}{ Férfiak } \\
\hline Közép-Magyarország & $-0,63$ & 2,41 & 1,31 & 0,70 & 1,87 & 5,66 \\
\hline Közép-Dunántúl & $-0,03$ & 2,51 & 1,05 & 0,33 & 1,24 & 5,10 \\
\hline Nyugat-Dunántúl & $-0,17$ & 1,75 & 0,82 & 0,33 & 1,29 & 4,03 \\
\hline Dél-Dunántúl & 0,01 & 2,28 & 0,66 & 0,28 & 1,56 & 4,79 \\
\hline Észak-Magyarország & $-0,16$ & 2,52 & 0,68 & 0,22 & 1,05 & 4,30 \\
\hline Észak-Alföld & $-0,33$ & 2,53 & 0,63 & 0,25 & 1,58 & 4,66 \\
\hline Dél-Alföld & $-0,20$ & 2,29 & 0,71 & 0,26 & 1,47 & 4,53 \\
\hline Vidéki régiók & $-0,28$ & 2,43 & 0,82 & 0,30 & 1,03 & 4,31 \\
\hline Együtt & $-0,33$ & 2,36 & 0,91 & 0,40 & 1,52 & 4,87 \\
\hline \multicolumn{7}{|c|}{ Nők } \\
\hline Közép-Magyarország & $-0,58$ & 1,41 & 1,42 & 0,47 & 1,64 & 4,36 \\
\hline Közép-Dunántúl & 0,43 & 1,04 & 0,85 & 0,09 & 1,82 & 4,23 \\
\hline Nyugat-Dunántúl & $-0,24$ & 0,92 & 0,80 & 0,20 & 1,88 & 3,56 \\
\hline Dél-Dunántúl & $-0,19$ & 0,74 & 0,80 & 0,13 & 2,55 & 4,03 \\
\hline Észak-Magyarország & 0,06 & 0,96 & 0,76 & 0,14 & 1,41 & 3,33 \\
\hline Észak-Alföld & 0,23 & 0,94 & 0,71 & 0,15 & 2,03 & 4,08 \\
\hline Dél-Alföld & 0,25 & 0,77 & 0,71 & 0,15 & 1,53 & 3,41 \\
\hline Vidéki régiók & 0,00 & 0,87 & 0,79 & 0,16 & 1,94 & 3,77 \\
\hline Együtt & $-0,18$ & 1,11 & 0,99 & 0,26 & 1,75 & 3,93 \\
\hline
\end{tabular}




\section{THE IMPACT OF IMPROVING EDUCATION ON LIFE EXPECTANCY IN HUNGARY}

\section{ABSTRACT}

In the beginning of the 90s, an epidemiologic turn happened in Hungary, during the following decades, the life expectancy of the population increased constantly. Most studies explain the improvements of life expectancy as a result of more modern therapeutic methods and the changes in the quality of health care. Others highlight the improvement of living standards and the change in health behaviour and attitudes.

Between education and mortality, there is a strong and well-documented relationship. Contrary to this, while explaining the changes, the fact that the Hungarian society transformed significantly is emphasised less. The proportion of those who graduated from secondary school or a degree has increased while the proportion of those with not even elementary education has decreased significantly.

Using the replacement decomposition technique proposed by Andreev (2002) the change of life expectancy was separated into changes in population structure (P-effect) and changes in the mortality of the groups (M-effect). The positive change in population structure contributed to a 1.5-year increase in life expectancy between 1990 and 2011 for women and a 1.45-year increase for men over the same period.

In other words, during the analysed period, out of the improvement of life expectancy, the population effect was equal to the improvements of 8.5 calendar years for women and made up the average improvement of 6.5 years for men.

The principal message of this study is, that education policy is a really effective health political instrument. Education makes possible to acquire such knowledge, which helps us to prevent and treat illnesses. It is important, that the decision makers and healthcare professionals understand the significance of education, which not only results in the constant improvement of life expectancy but is able to moderate socioeconomical inequalities as well. 